\title{
Research Paper \\ Dimension Exploration of Multi-dimensional Model of Parenting of Children with Attention Deficit Hyperactivity Disorder (ADHD) and its Effect on Parent-Child Interaction: A Mix Methods Research
}

\author{
Arezoo Shahmiveh Isfahani ${ }^{1}$, Ahmad Abedi ${ }^{* 2}$, Salar Faramarzi ${ }^{2}$, Ahmad Yarmohamadiyan ${ }^{2}$ \\ 1. Ph.D. in Psychology of Children with Special Needs, Faculty of Educational Sciences and Psychology, University of Isfahan, Iran \\ 2. Associate Professor, Department of Psychology of Children with Special Needs, Faculty of Educational Sciences and Psychology, \\ University of Isfahan, Iran
}

Citation: Shahmiveh Isfahani A, Abedi A, Faramarzi S, Yarmohamadiyan A. Dimension exploration of multi-dimensional model of parenting of children with attention deficit hyperactivity disorder (adhd) and its effect on parent-child interaction: a mix methods research. Quarterly Journal of Child Mental Health. 2020; 7(2): 241-256.

http://dx.doi.org/10.29252/jcmh.7.2.21

\section{A R T I C L E I N F O}

Keywords:

Multidimensional parenting model, attention deficit hyperactivity disorder (ADHD), parent-child interaction

Received: 15 May 2018 Accepted: 23 Oct 2018 Available: 21 Sep 2020

\section{A B S T R A C T}

Background and Purpose: Attention Deficit Hyperactivity Disorder (ADHD) is a neurodevelopmental disorder. Its treatment specifically needs parental training. Most parents of children with ADHD show revengeful and confrontational behavior towards them and use ineffective parenting strategies that may increase the symptoms of this disorder and influence the parent-child interaction.

Method: Regarding the subject of this research, the exploratory mixed methods design was used. First, at the qualitative stage, problems of children with ADHD and problems of their parents were identified and encoded through content analysis and review of articles and books. Then, educational and therapeutic models and programs related to these problems were investigated. Next, the qualitative findings were used to create a parenting model. At the quantitative stage, this model was taught to 10 mothers of children with ADHD over 16 two-hour sessions for two months. Then their parent-child interaction was compared with the control group. Purposive sampling was used at the qualitative stage. The sample was selected by purposive sampling at the quantitative stage and then randomly assigned to either the experimental or control group (10 per group). Child-Parent Relationship Scale (CPRC) (Pianta, 1992) was used as the study tool. Data were analyzed by repeated-measures ANOVA at 95\% confidence level with SPSS20.

Results: In content analysis, 10 themes and 50 sub-themes in the area of problems of children with ADHD were identified and then the sessions were organized based on them. Results of quantitative stage showed that the mean difference of the total score and all the sub-scales (conflict, positive relationship, and dependency) was significant at pretest, posttest and follow-up stages $(\mathrm{P}<0.05)$, indicating that multidimensional parenting model training can enhance parent-child interaction.

Conclusion: Results showed that multidimensional parenting model training (based on the problems of children with ADHD) is more suitable for the etiology and symptoms of this disorder and it is a mixture of different methods that have been shown to be effective based on different studies, so it can be effective on the enhancement of parent-child relationship.

\footnotetext{
* Corresponding author: Ahmad Abedi, Associate Professor, Department of Psychology of Children with Special Needs, Faculty of Educational Sciences and Psychology, University of Isfahan, Iran.

E-mail addresses: A.abedi@edu.ui.ac.ir
} 


\section{كشف ابعاد الكوى والدكرى جندبعدى كود كان با اختلال نارسايى توجه / فزون كنشى و

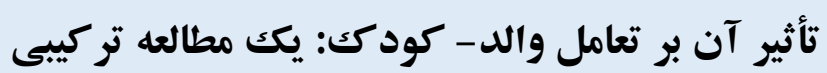

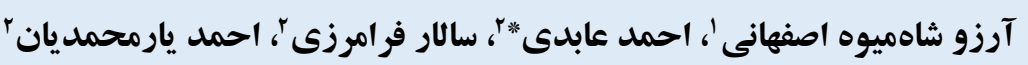

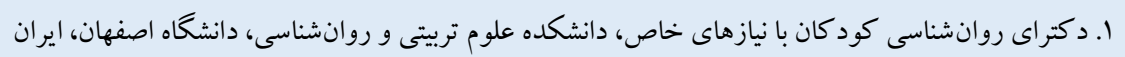

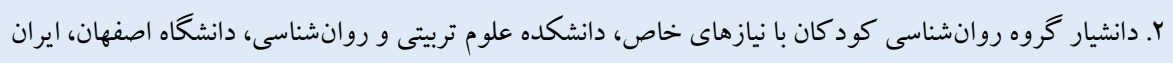

جكيده

زمينه و هدف: نارسايى توجه / فزون كنشى، اختلالى عصبى تحولى است كه در خط مقدم درمان آن، آموزش والد ين جايكاه و ويزٔهاى دارد.

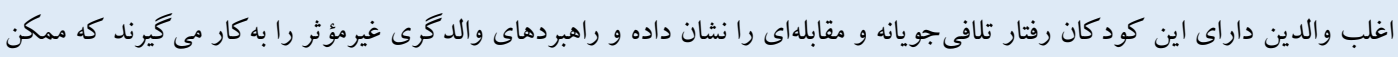

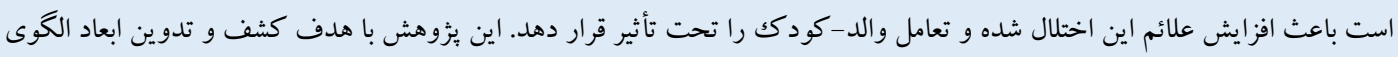
والدكرى جندبعدى و اثربخشى آن بر تعامل والد - كود كك انجام شد.

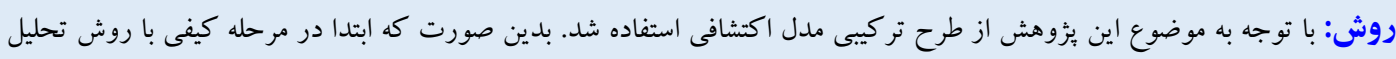

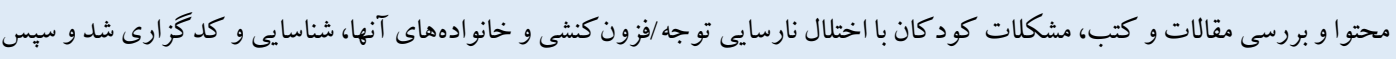

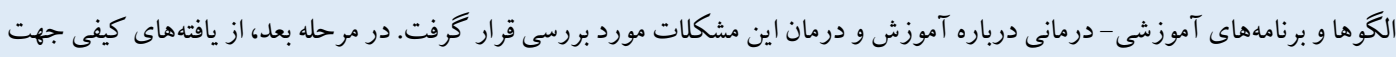

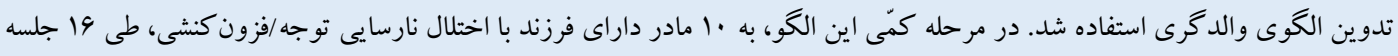

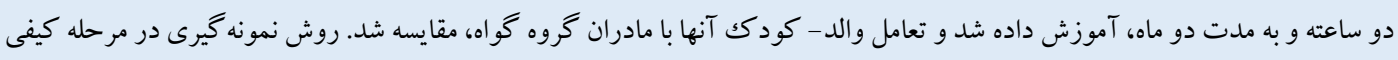

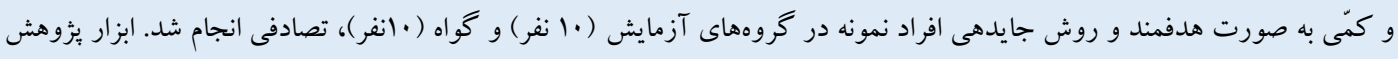

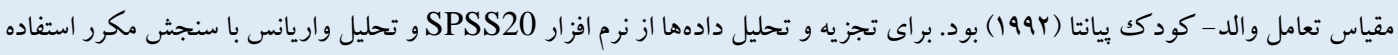

يافته ها: در تحليل محتوا ال 1 مضمون اصلى و .ه مضمون فرعى در زمينه مشكلات اين كود كان شناسايى و با توجه به آنها، جلسات مداخله

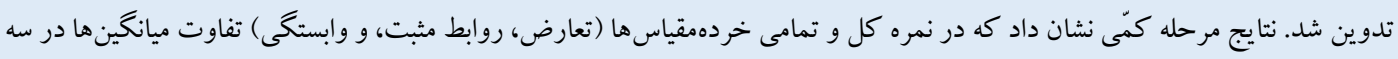

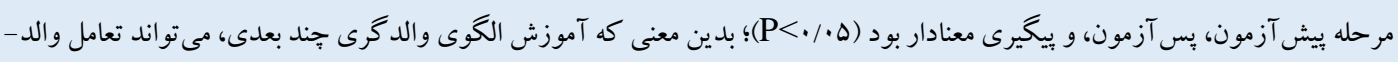
كود كك را بهبود بخشد.

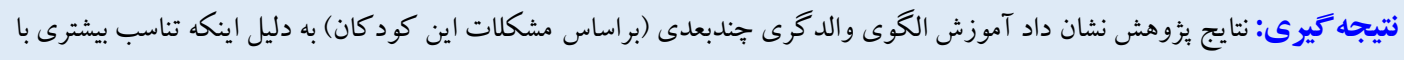

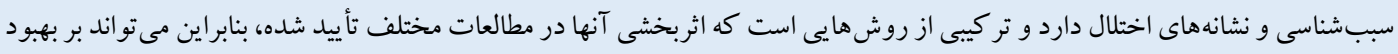
روابط والد - كو كك مؤثر باشد.
مشخصات مقاله

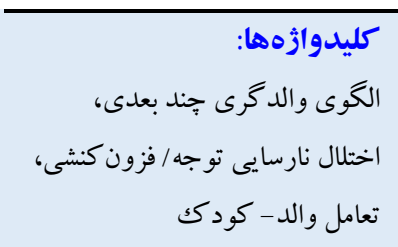

كليدوازهها:

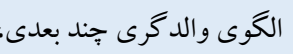

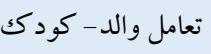


خودارزشـمندى را گزارش كردهاند و از سـبك هاى والدگرى منفىتر و

متناقض ترى استفاده مى كنند (Nو و F (I).

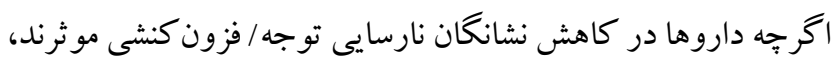

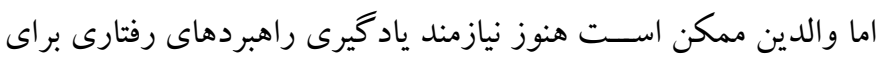

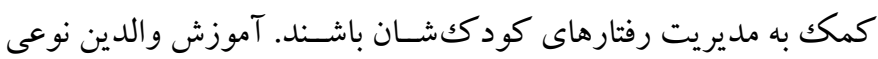

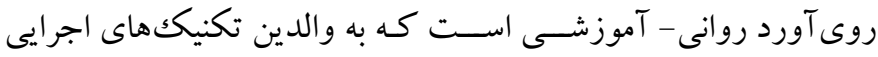

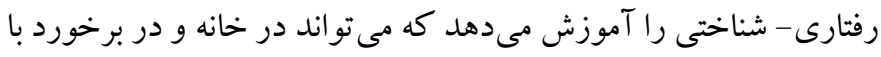

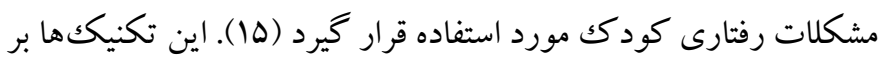

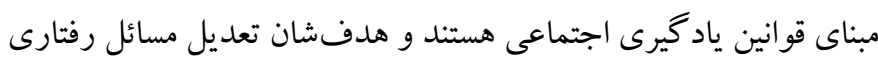
در محيط كودكك است. تغييرات در سوابق محيطى (ماند فرمان دادنها)،

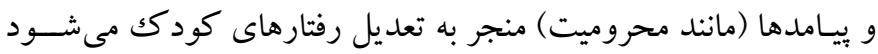

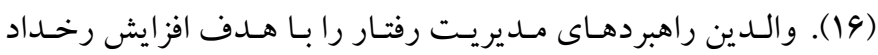

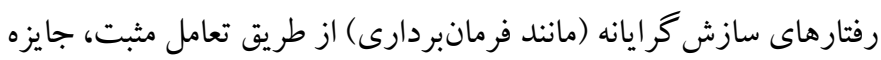

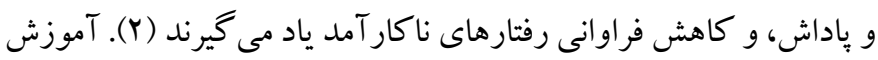

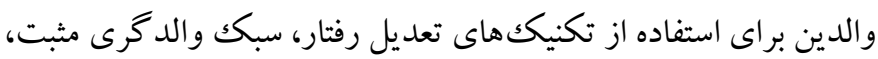
و كاهش اسـتفاده از سـبككهاى والدكرى خشـن و ناملايم، علائم اختلال

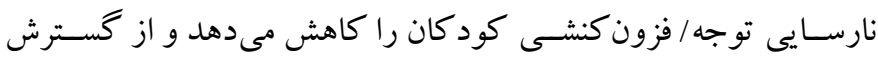

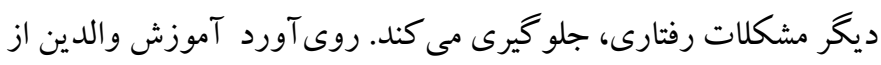
روشهاى ترجيحى در درمان اختلال نارسايى توجه / فزون كنشى و اختلال نافرمانى مقابلهاى است و شو اهدى وجود دارد كه نشان مى دهند اين شيوه

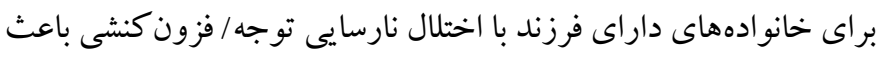

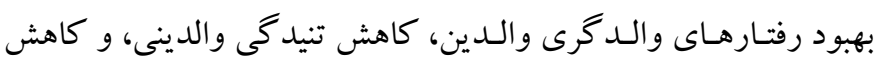

$$
\text { مشكلات رفتارى كود كك مى شود (IV). }
$$

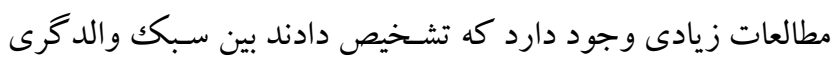
و الدين كود كان با اختلال نارسايى توجه/ فزون كنشى با كود كان فاقد اين

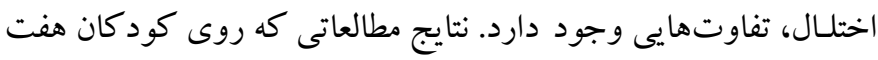

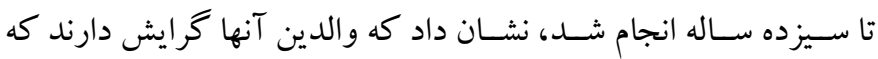

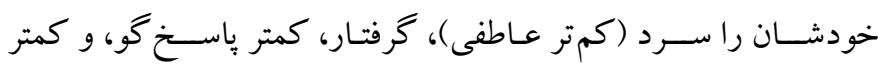

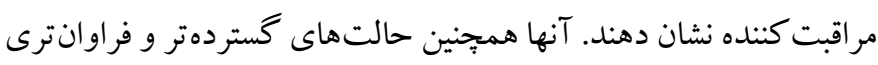

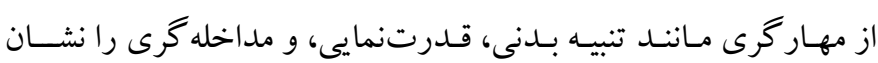

3. Conduct disorder
مقدمه

اختلال نارسـايى توجه / فزون كنشى ' يكى از شـايع ترين اختلالات تحولى

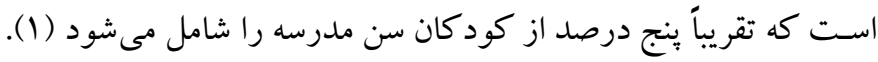

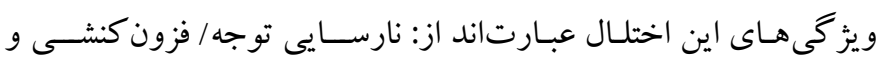
تكانشـرى كه در دو محيط يا بيشتر (مثل خانو اده يا مدرسـه) نمود بيدا مى كنـــ و عملكرد كود كك را دجّار اشــكـال مى كنـــ (Y). اين اختلـال همجِنين با ديخر انواع مشكلات سلامت روان نيز ممكن است همر اه باشد؛

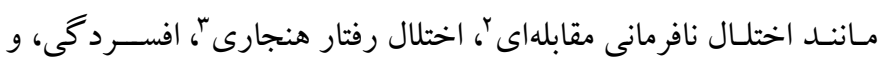

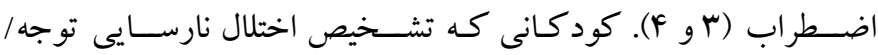
فزون كنشى دريافت مى كنند، بيشتر در معرض خطر گروهى از مشكلات

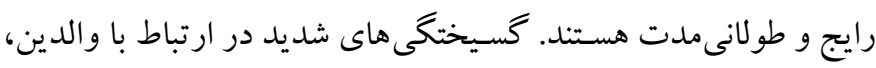

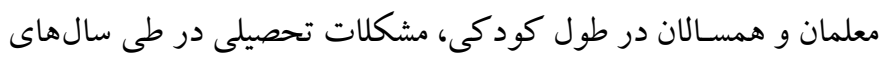

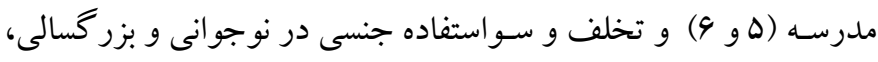

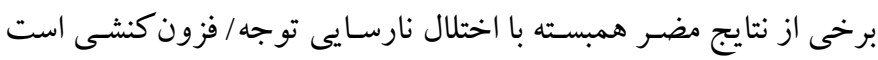

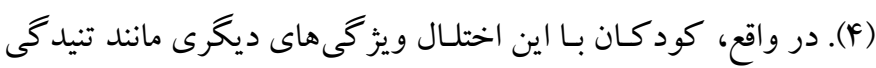

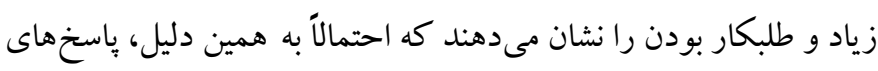

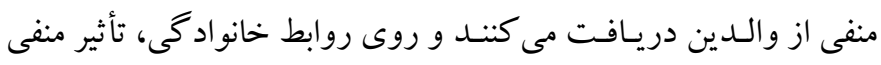

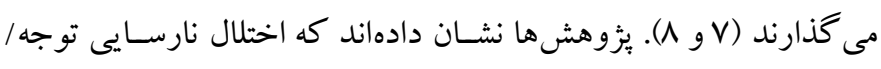

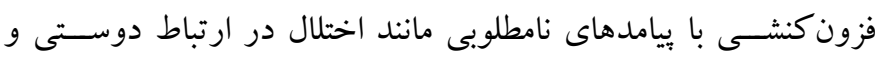
خانو ادگىى، كاهش مشـار كت در فعاليتهاى عملكردى داخل و خارج

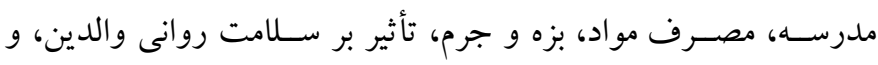

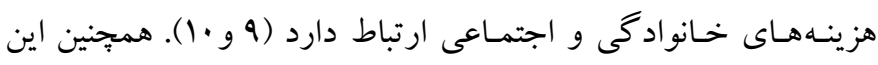

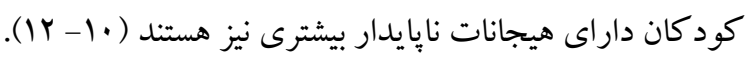

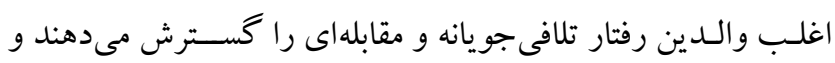

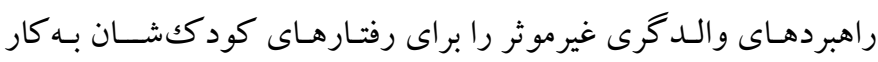

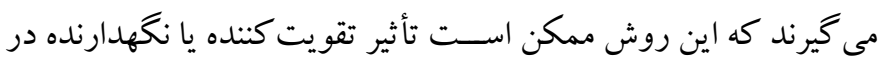

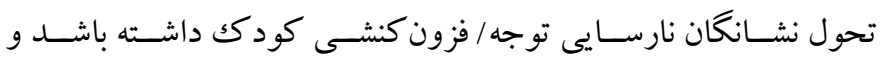

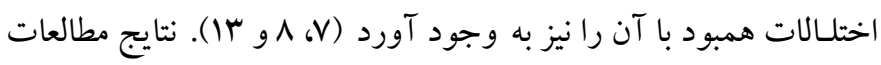

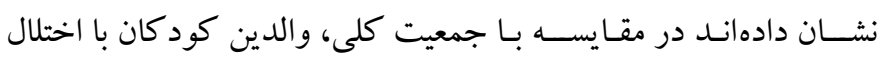

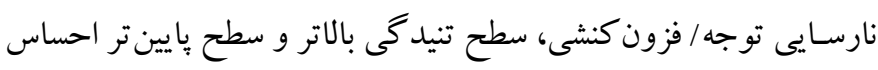




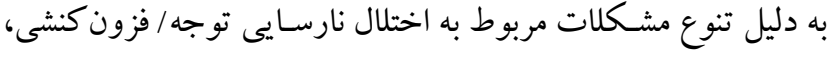

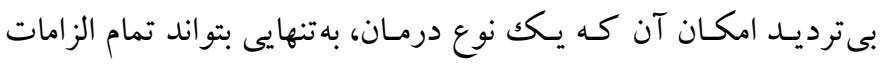

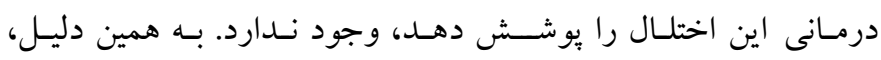
متخصصـان اغلب راهبردهاى درمانى متعددى را در تر كيب با هم اتخاذ

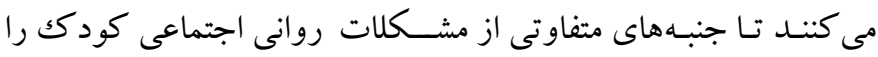

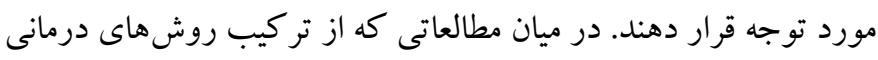
مـانتـد دارودرمانى و درمـان رفتـارى حمـايت مى كنند، مطالعات درباره

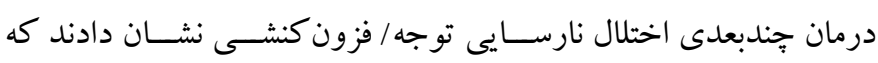

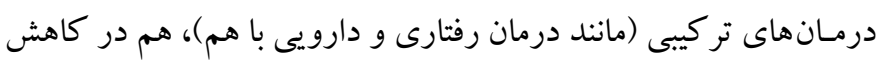

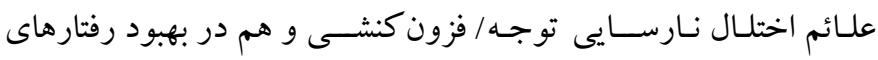

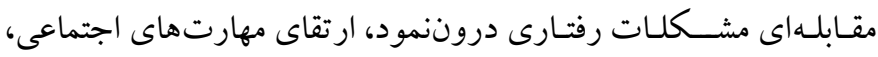
دستاوردهاى تحصيلى، و تعاملات والد-كود كك، مؤثر هستند. بر ایى مثال دو مطالعه فراتحليل كه درمان دارويى، درمان رفتارى، و تر كيب آنها را

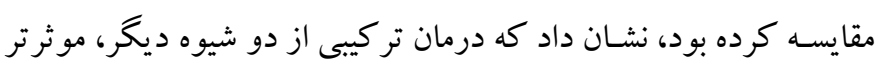

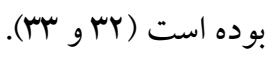

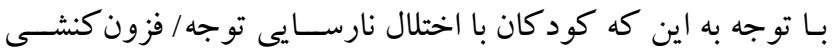
مشـكلاتى در زمينه توجه، مهار تكانه، و انجام تكاليف تحصسيلى دارند و

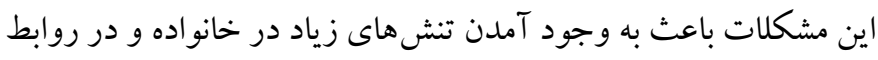

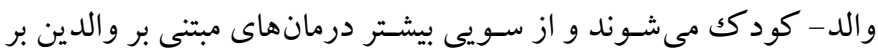

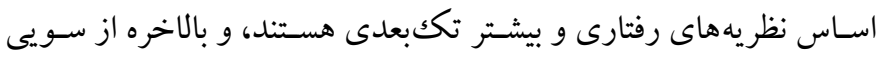

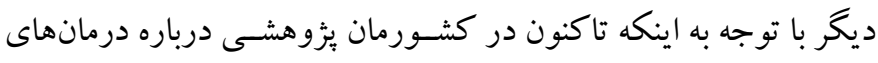

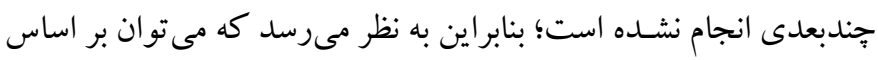

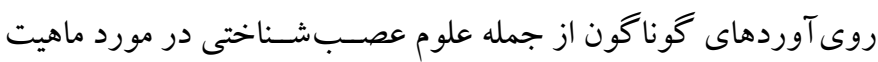

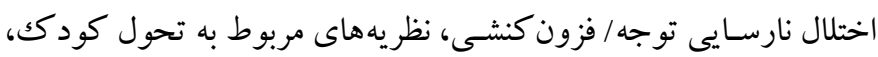

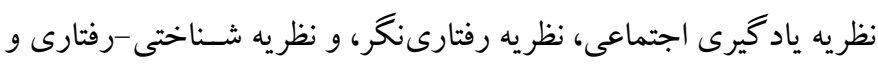

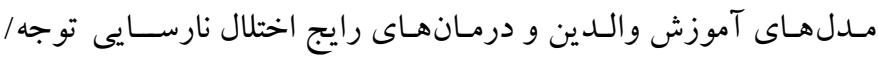

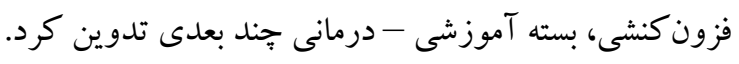

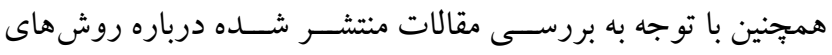

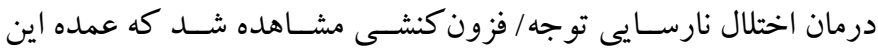

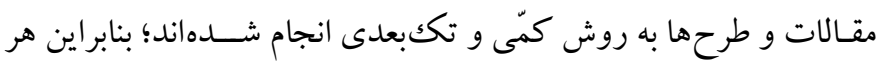

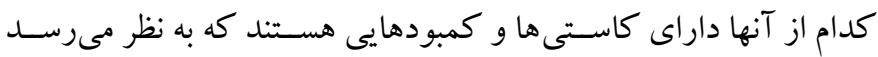

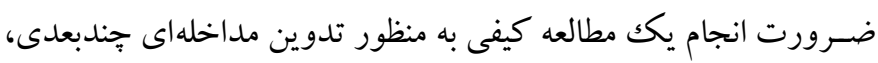

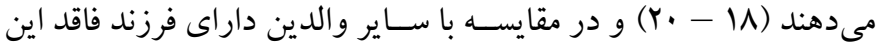
اختلـال، ناهماهنكى بيشــترى دارند (Y) (Y). در مطالعهاى كه فقط ديد كاه

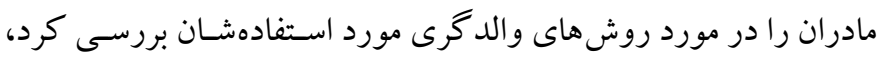

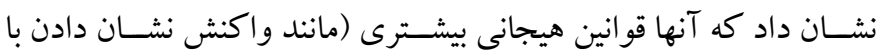
محرومسازى بيشاز اندازه، كج خلقى، و خشم) را استفاده مى كنند (Yr).

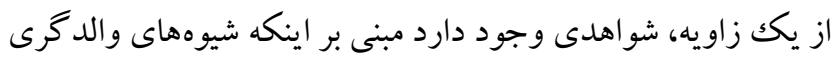

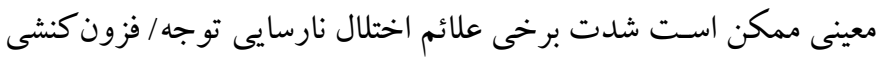

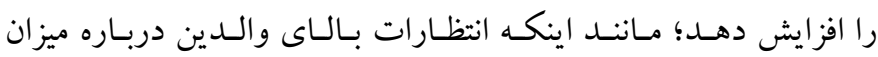

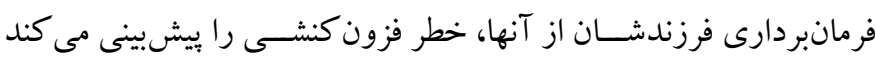

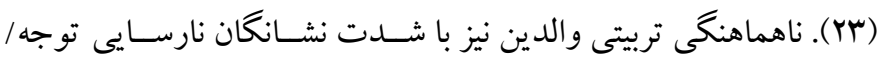

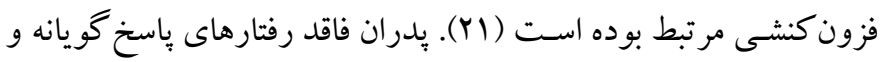

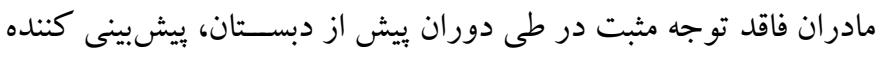

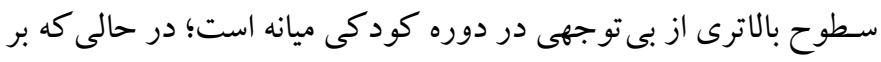

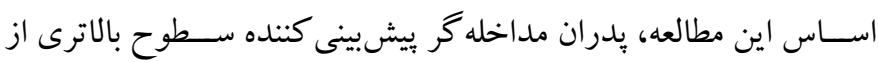

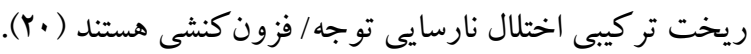

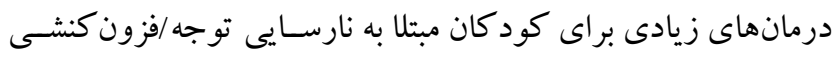

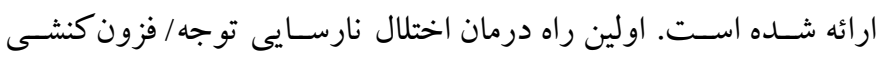
درمان دارويى اسـت، اما براى ســين هيايين تر، درمان غيردارويى از جمله

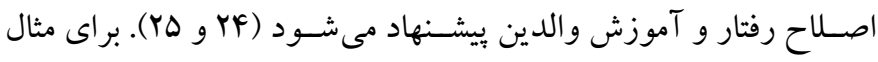

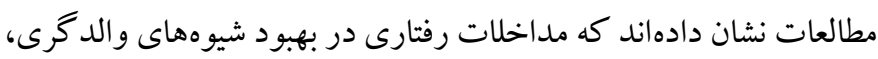
مشـكلـات رفتـارى كود كـان، مهارتهـاى اجتماعى، و دســتاوردهاى

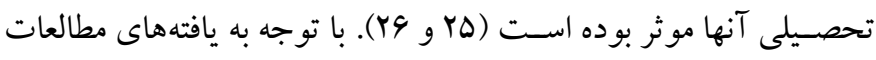

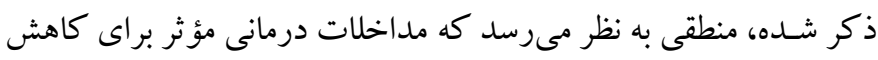

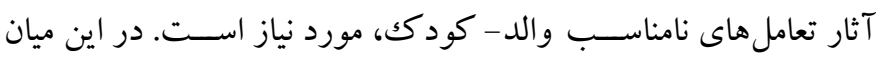

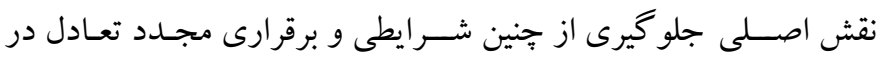

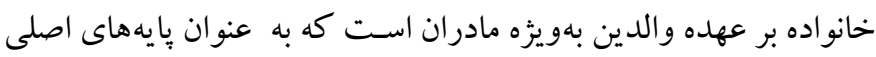

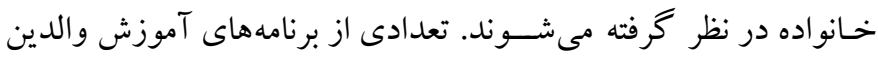

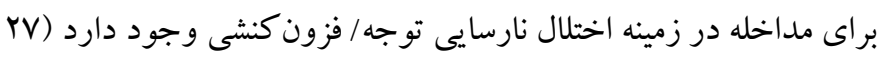

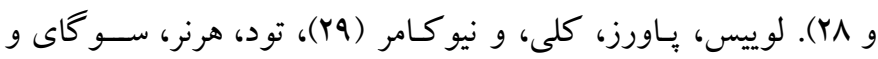

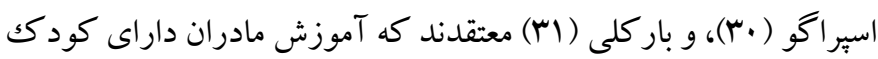
با اختلال نارسايى توجه/ فزون كنشى در بهبود روابط آنها با كود كانشان موثر است. 
مقـالـات و كتـب داخلى و خـارجى مرتبط بـا اختلـال نـارســيى توجه/ فزون كنشى، تعداد ·بr مقاله و كتاب انتخاب شده و مورد تحليل محتوا قرار گرفتند.

روش نمونسه گيرى مرحله كمّى نيز بـه صسـورت هدفمند و جايدهى

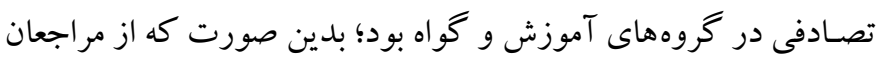

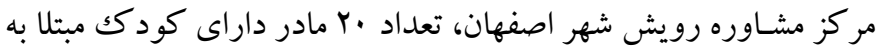
اختلال نارسـايى توجه/ فزون كنشسى بر حسـب ملاككهاى ورد و و خروج

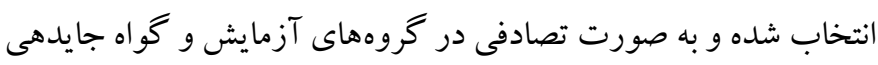

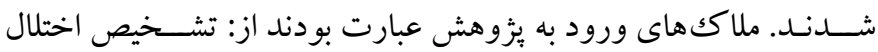

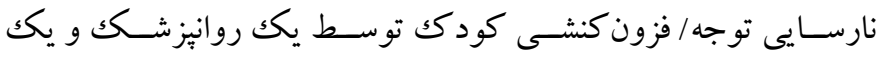

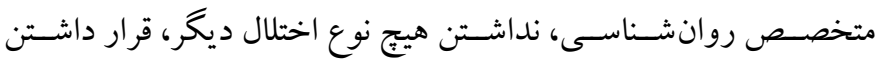
كود كك در دامنه سنى مورد نظر، و رضايت كتبى مادران براى شركت در

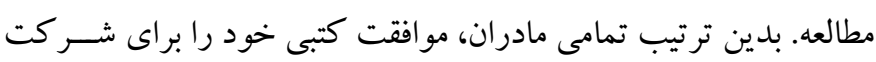
در يززوهش اعلام كردند و تا يايان جلسات، حضور فعال داشتند.

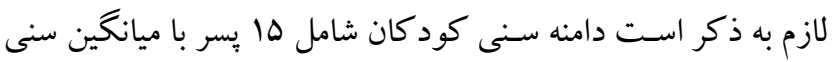

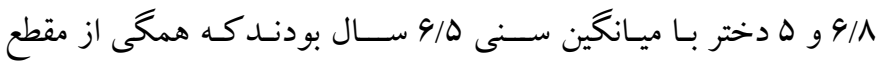

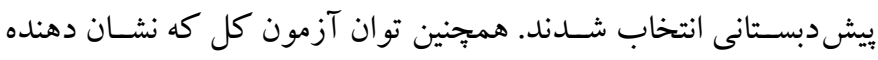

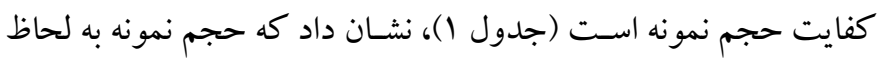

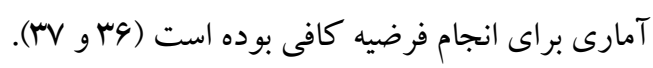

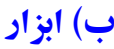

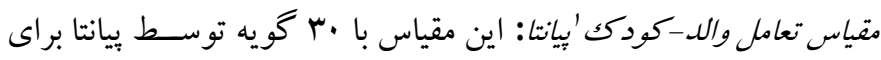
ارزيابى كيفيت روابط والد ــ كودك سـاخته شده است. كويههاى اين

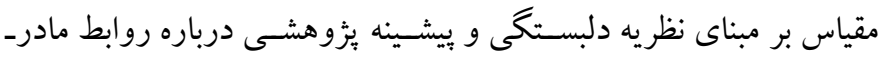

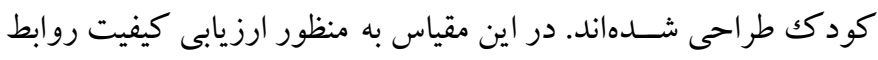

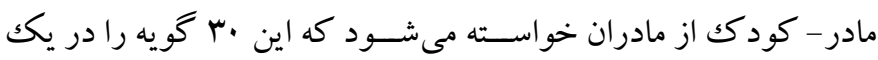

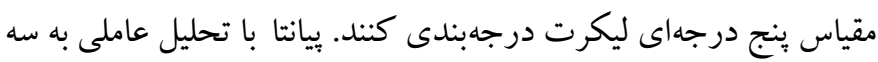

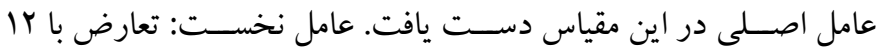

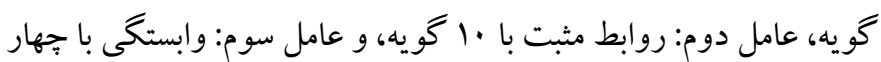

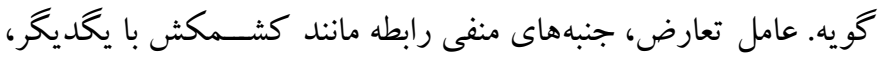

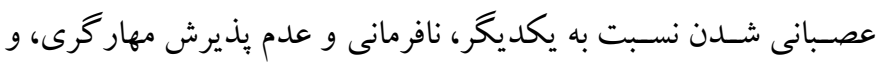

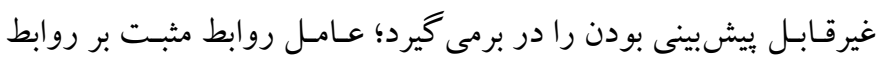

محسوس است تا بتو انيم به درك عميق تر از اين اختلال در درمان برسيم.

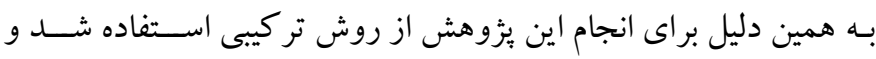

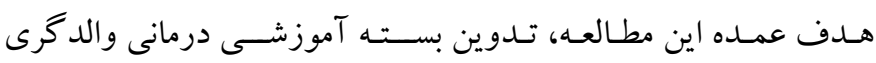
جندبعدى و بررسى تأثير آن بر تعامل والد- كودكك بوده. در بخش كيفى، مهم ترين موضــوع اين مطـالعه، كشـف مؤلفه مهاى درمـان جندبعدى بر اسـاس مشــكلات والدين و كود كان داراى اختلال نارسـايى توجه / فزون كنشسى و روش هاى درمانى موثر براى اين اختلال

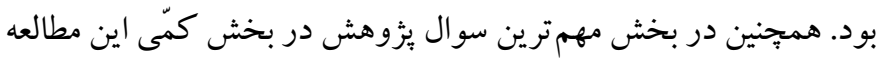

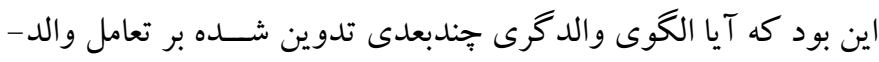

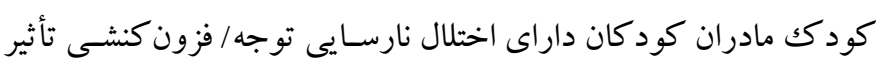

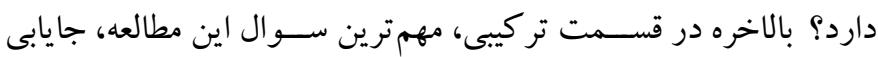

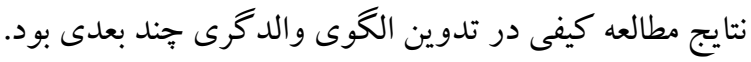

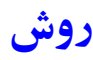

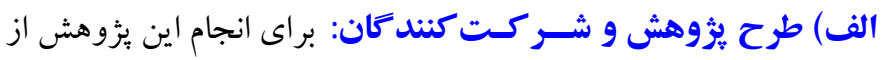

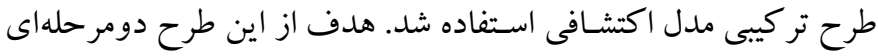

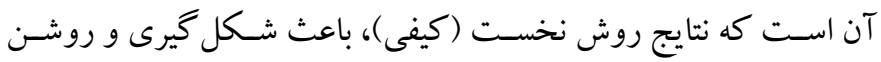

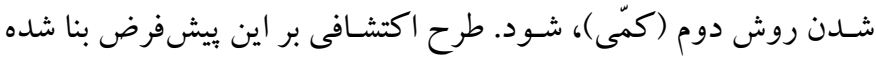

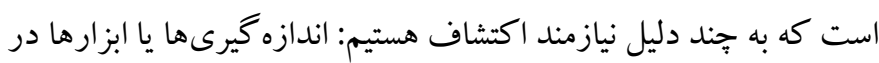

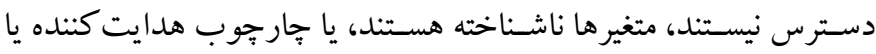
نظريـهاى وجود ندارد. از آن جايى كه اين طرح به صــورت كيفى آغاز مىشود، بيشتر مناسب كشف يكك يديده است (

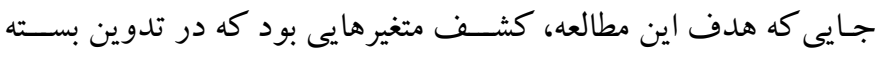

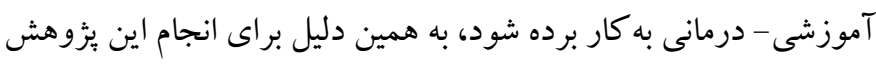
از روش تر كيبى اكتشافى استفاده شد. جامعه آمارى بخش نخسـت (كيفى) يزووهش شــامل تمامى منابع، مقالات، كتابها، و افراد متخصـص در حيطه اختلال نارسـايى توجه/

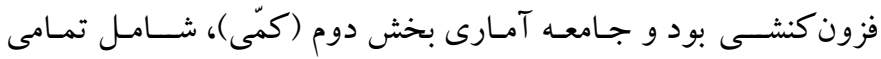

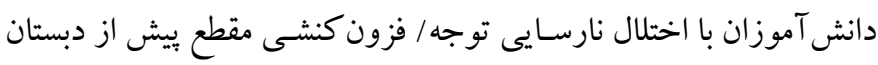

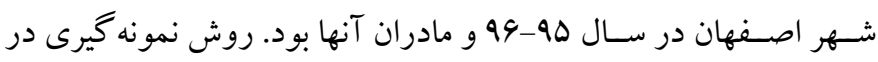

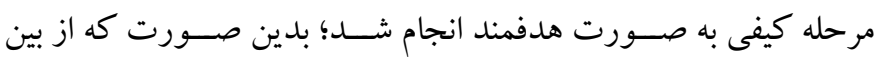


اختلال نارسايى تو جه / فزون كنشى، مشكلات با خو اهر بر ادرها، فشار مالى

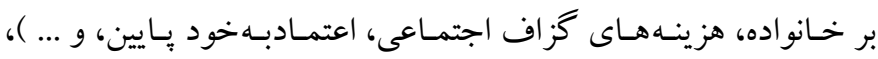

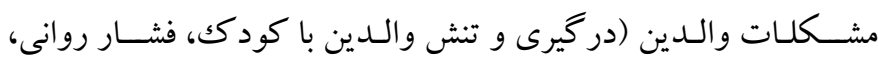

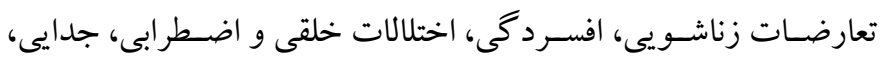
انزوا، احساس بى كفايتى و شرمسارى، خشم و عصبانيت، مهارطلبى، عدم

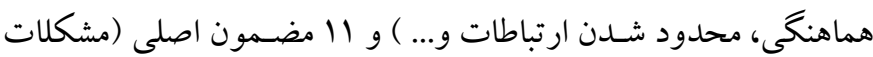
شناختى، مشكلات ادراكى - حر كتى، مشكلات رفتارى، مشكلات مادران،

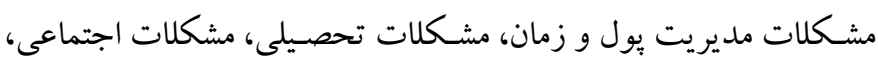

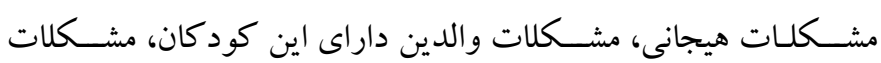

$$
\text { خانواده) تدوين شد (شكل ()). }
$$

بر اين اســاس درمـانهاى اين مشــكلات و مبانى نظرى آنها بيرون

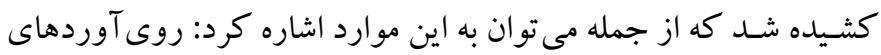

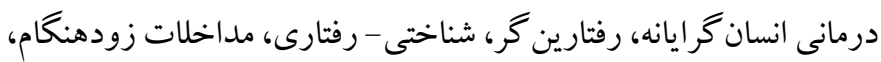

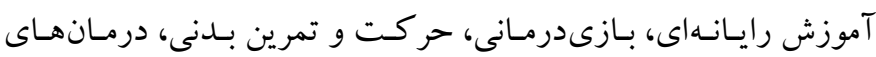
تر كيبى، و درمانهاى موج سوم). در نهايت بر اسـاس اين روى آوردهاى درمانى و مشـكلات كودكان

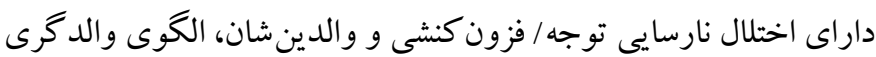

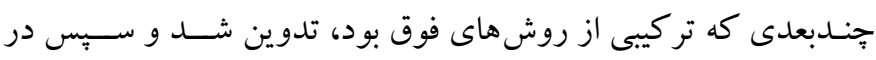

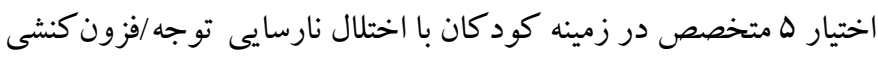

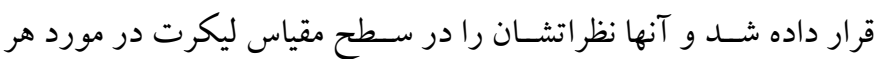
جلسه ارائه دادند. اين بسته طى 19 جلسه دو ساعته و دو روز در هفته بهمدت دو ماه، بر

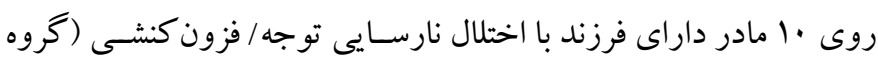
آزمايش) توسط ئزوهشخر در مركز مشـاوره رويش شهر اصفهان، اجرا

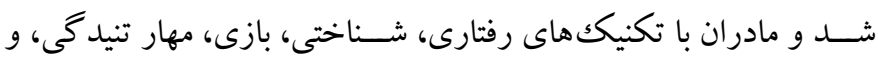

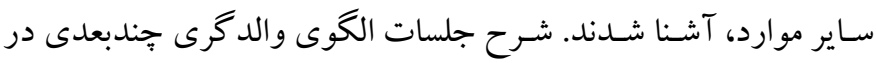
جدول ا ارائه شده است.
نزديكك و صسميمى كود كك - والد تأكيد دارد؛ و عامل وابستيخى، ميزان

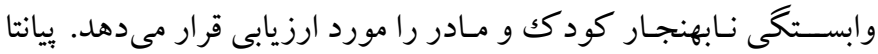

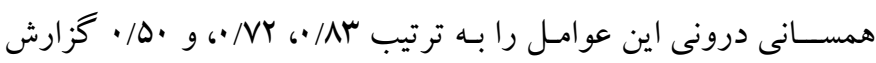

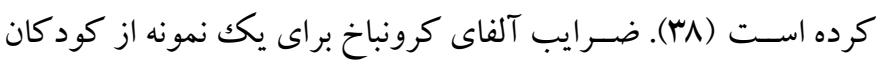

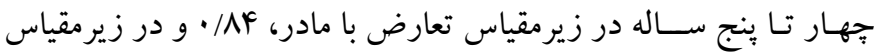
روابط نزديك،، 199. گزارش شد (19). روايى محتوا و اعتبار اين مقياس در ايران توســط خدإناهى، قنبرى،

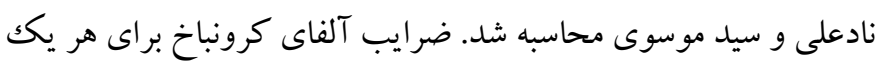

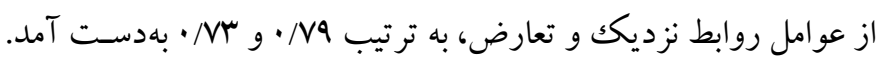

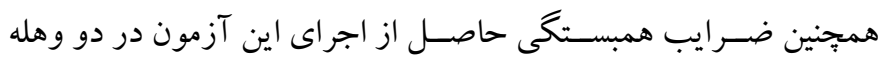

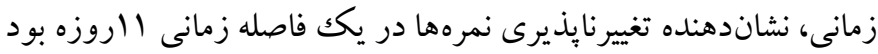

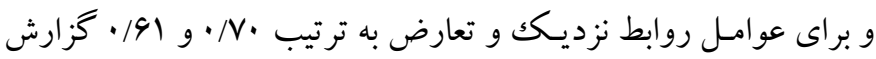
شد (F.) (F)

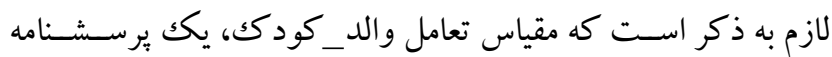

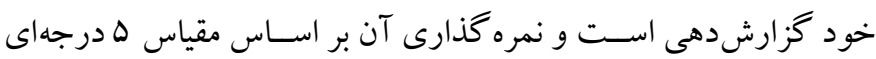

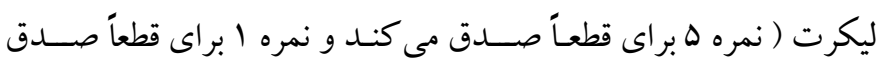

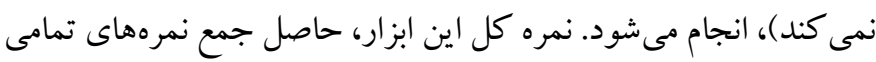

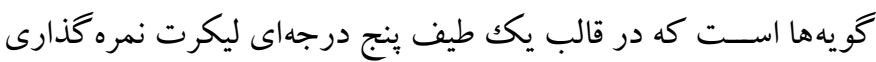
مى شـــود. در مورد زيرمقيـاس تعـارض نيز بـايــــ تومجـه داشـــت كـهـ

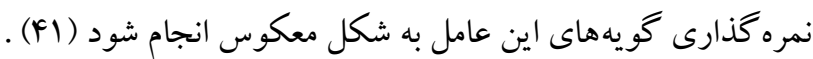

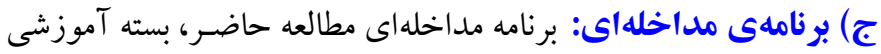

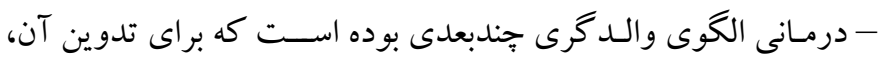

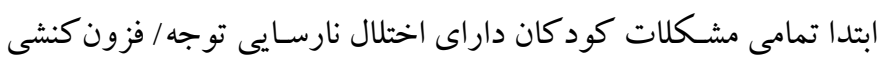
از • ·r منبع مختلف استخراج شـد. •ه مضـمون فرعى (از جمله: مشكل

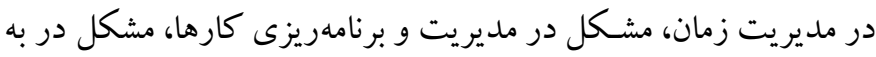
تعويق انـداختن لذت، ميانبر زدن، خطريذيرى بالا، رفتار قانون شـكـنانه،

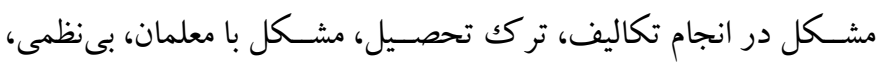

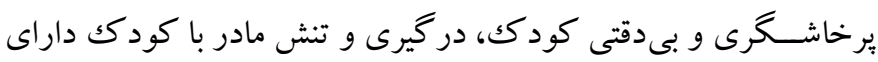




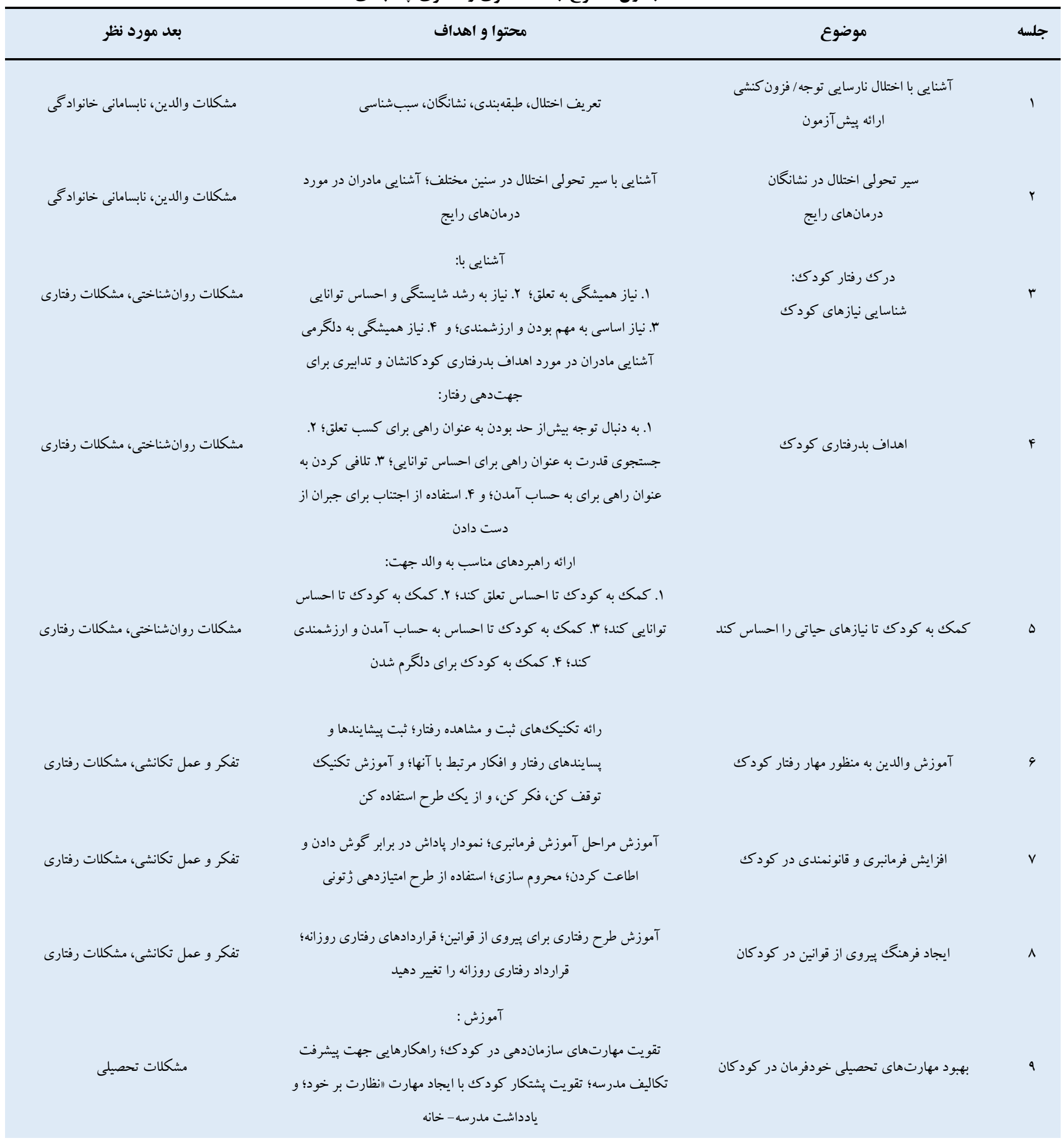




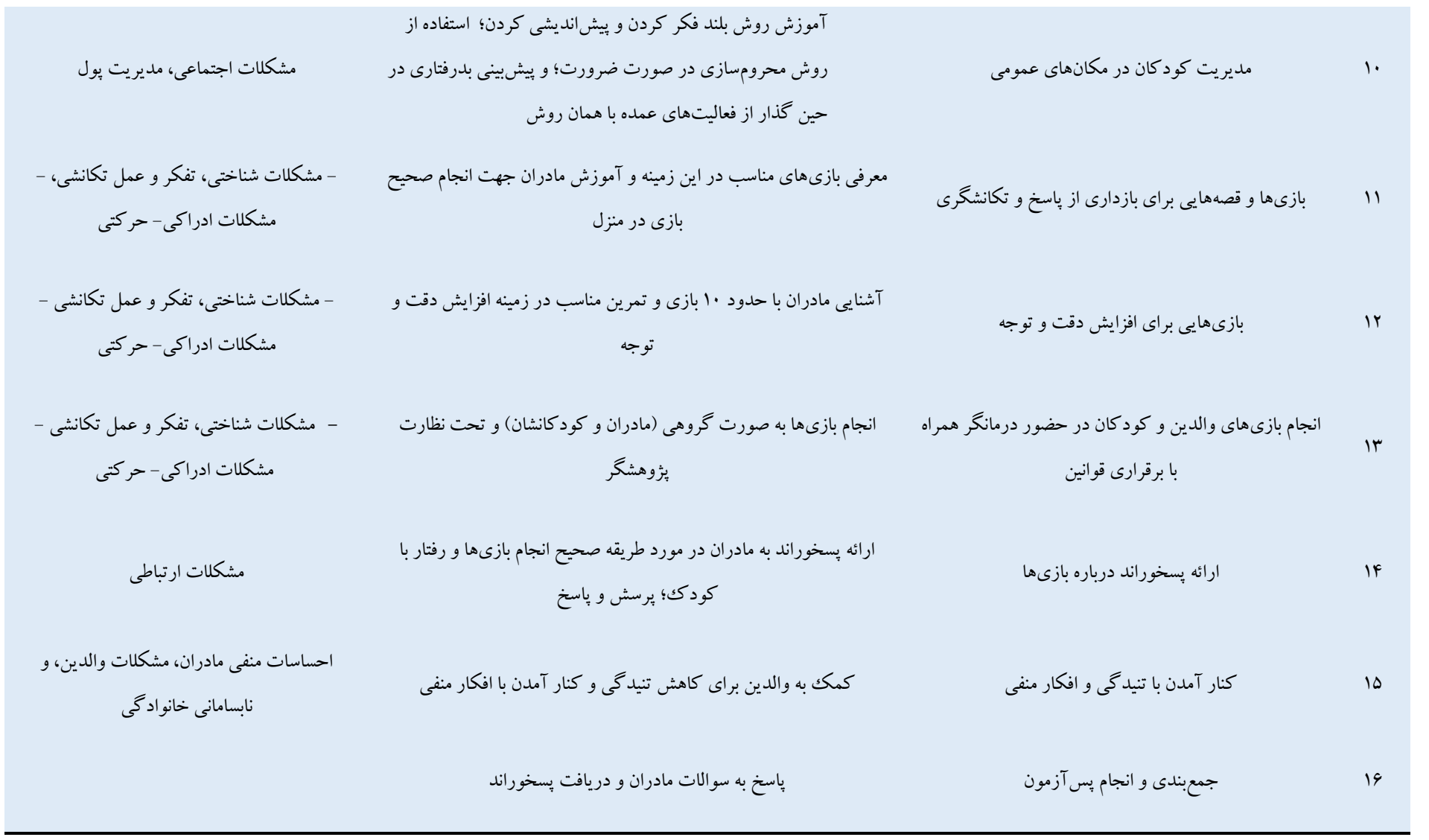

(لازم به ذكر اســت كه يافته هاى اين بخش به علت محدوديت در تعداد

وازههاى اين مقاله فقط به صورت مختصر ارائه شدند).

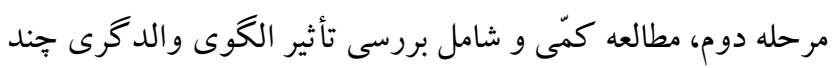

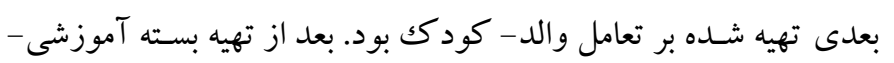

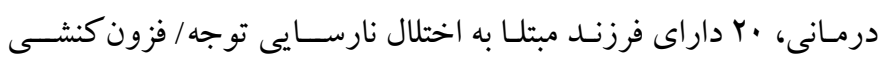
انتخـاب شـــند و به صــورت تصــادفى در گروههاى آزمايش و كو اه جايدهى شــند. اين بسـته طى 19 جلسـه بر روى مادران گروه آزمايش اجرا شـد. يكك ماه بعد از اتمام مداخله نيز نتايج بيكيرى جمع آورى شـد. كروه كواه ( •ا مادر) هيج آموزشسى دريافت نكردند و آنها در فهرست انتظار قرار گرفتند و بعد از يايان مداخله، آموزش دريافت كردند. يس از

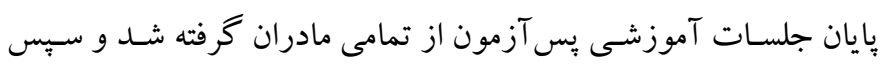

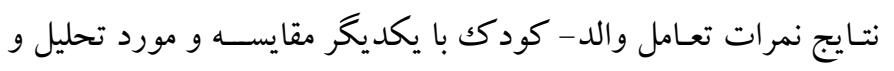
بررسى قرار كرفت. دياگر ام طرح به صورت زير بود (هץ).
د) روش اجر ا: اين مطالعه يكك طرح دو مرحلهاى بود. مرحله نخســت، يكك مطالعه كيفى و شـامل تهيه الكوى والدگرى جند بعدى بود. در اين مرحله از روش تحليل محتوا اسـتفاده شــــ كه يكلى از روشهاى انجام يُؤهش كيفى اسـت. واحد زمينه، كل متن مقاله ها و كتابهاى داخلى و

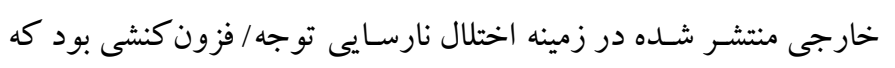
بعد از مطالعه · بr منبع، مقوله هاى اصسلى و فرعى طبقهبندى و شـناسـايى شدند. در تحليل محتوا || مضـمون اصسلى و حدود • له مضسمون فرعى در زمينه مشـكلات اين كود كان شناسايى شد، سيس راهكارهاى درمانى كه بر ایى اين مشكلات وجود داشت و روى آوردهاى نظرى آنها از يزٔوهش ها اسـتخراج شـد و بر اساس آنها، بسته آموزشى طراحى شده و سيس مورد آند تأييد ها متخصــص روانشــناسـى كه در زمينه كود كان داراى اختلال نارسـايى توجه / فزون كنشى نيز فعاليت علمى و بالينى داشتند، قرار كرفت 


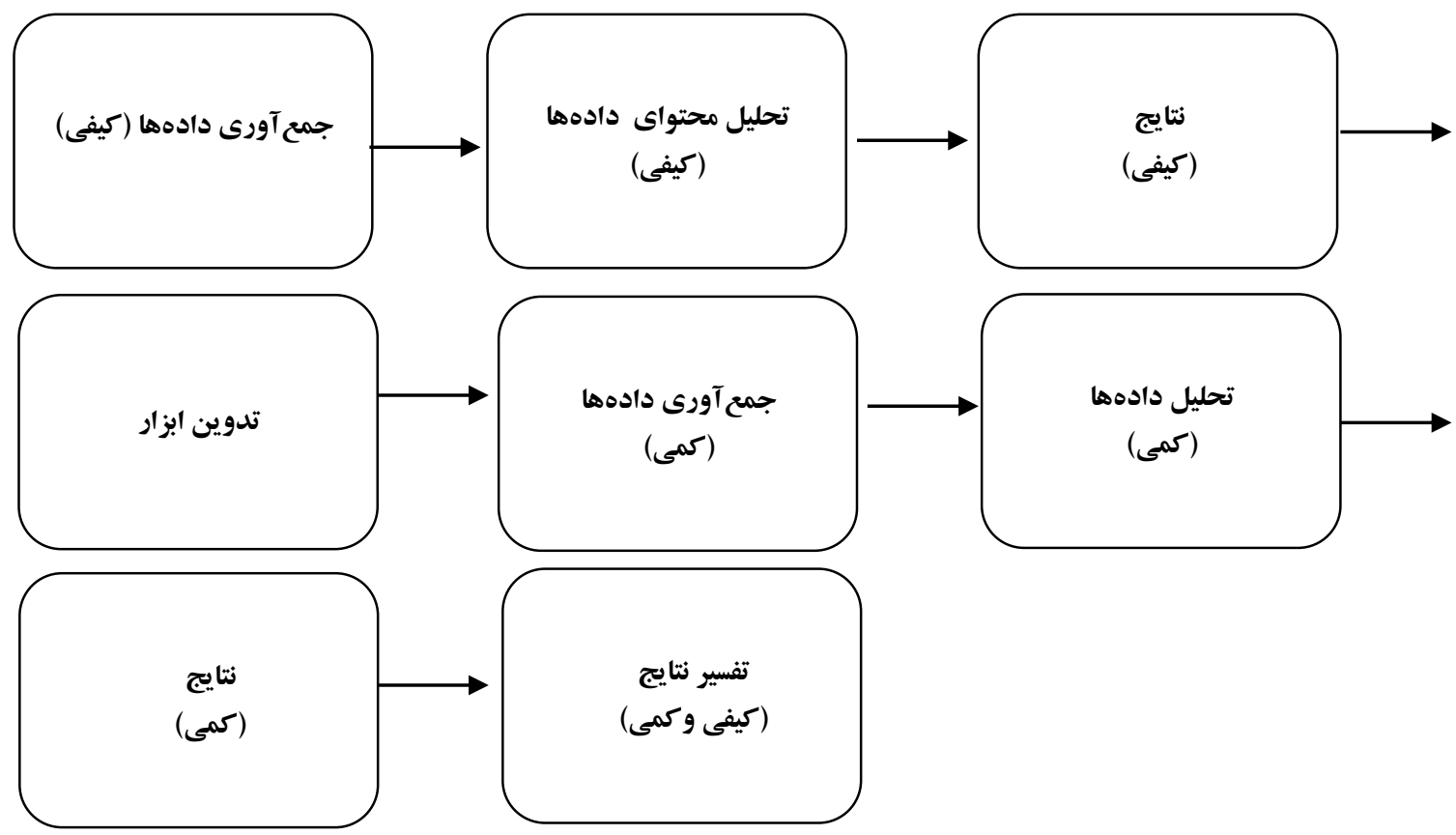

بر اسـاس يـك طيف جهار قسـمتى مشـــص مى كنند. در اين روش

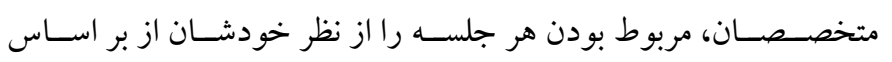

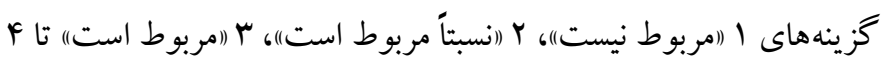

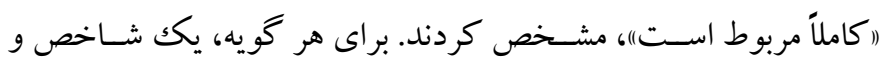

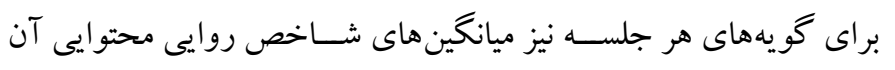
جلسه محاسبه شد. حداقل مقدار قابل قبول براى شاخص روايى محتو مايى

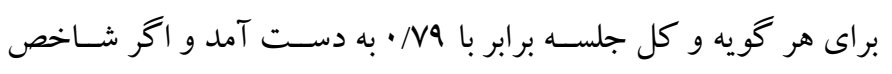

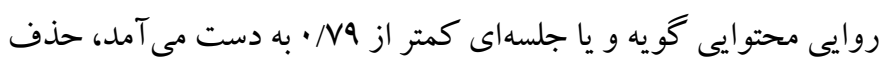

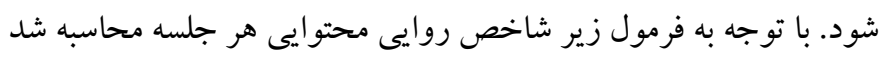

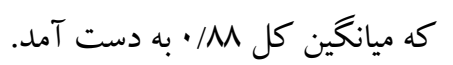

به دليل رعايت اخلاق يزوهشس بس از بايان بزوهش، گروه گ گواه نيز

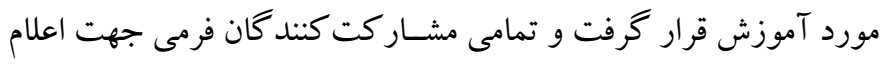

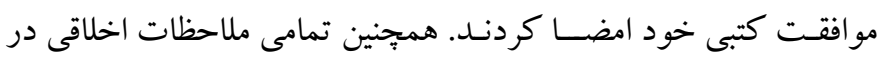

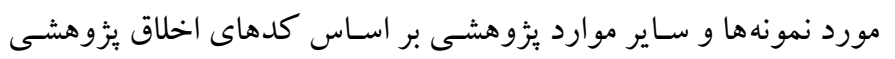
كشور، رعايت و تنظيم شد.

\section{يافته ها} مرحله كيفى: همان طور كه در بخش قبلى اشـاره شــــ هدف از مرحله

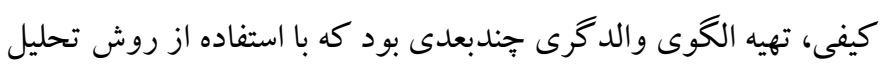

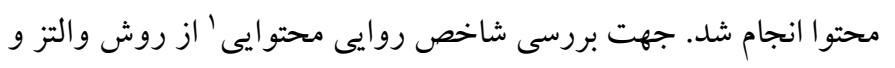

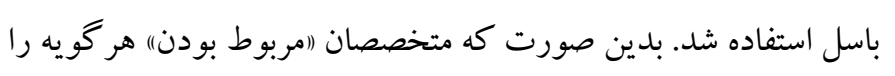

$$
\text { تعداد كل متخصصان }
$$

در تحليل محتوا | 1 مضمون اصلى و حدود •له مضمون فرعى در زمينه

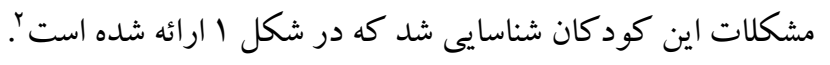




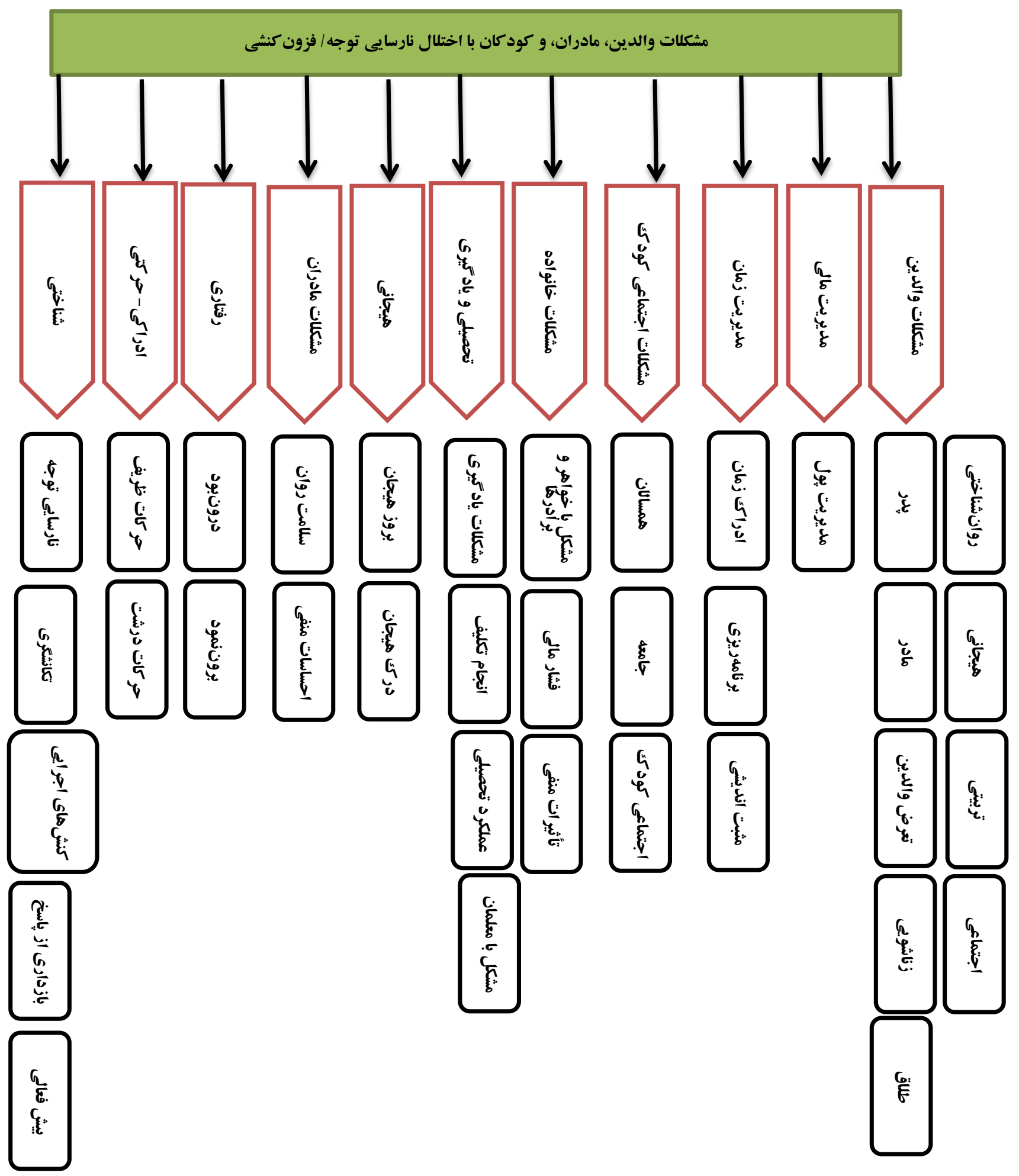

شكل 1: مضامين اصلى و فرعى استخراج شده درباره مشكلات كودكان با اختلال نارسايع توجه/ فزون كنشى و والدين آنها 


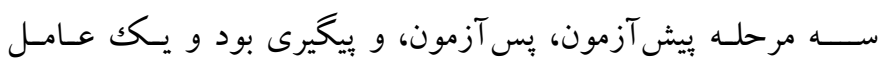

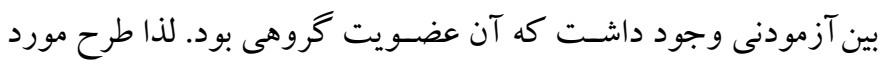
استفاده طرح درون-بين آزمودنى است. در جدول بـ بن بنايج آزمون تحليل واريانس با تكرار سنجش براى گروهها ارائه شده است.
مرحله كمّى: براى بررسـى تاثير آموزش الكوى والدگرى جندبعدى

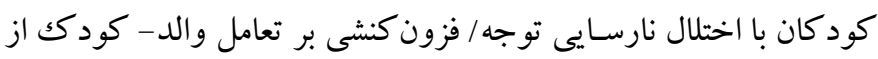

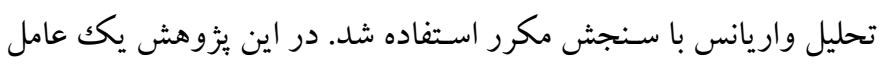

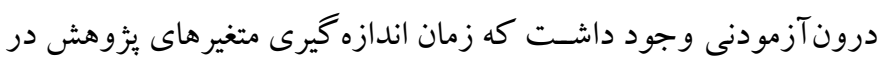

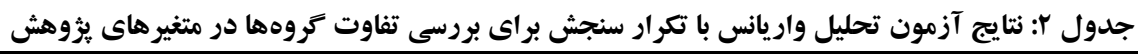

\begin{tabular}{|c|c|c|c|c|c|c|c|}
\hline توان آمارى & سطح معنادارى & Tاره & ميانكين مجموع مجذورات & درجه آزادى & مجموع مجذورات & منابع تغييرات & متغير \\
\hline 1 &.$/ \cdots 1$ & $9 M F / A 1$ & $q ৭ \mid F \Delta / r \Delta$ & 1 & $99 / F \Delta / r \Delta$ & أم & \\
\hline 1 & $\cdot / \cdots \cdot$ & $r Q / \Delta r$ & $191 / \cdot 1$ & $1 / \cdot 9$ & QFY/T. & مراحل & تعارض \\
\hline.$/ 91$ & $\cdot \cdots \cdot 1$ & $|N / 9|$ & $\Delta \Delta I / \Gamma \wedge$ & $1 / .9$ & G.r/fr & تعامل مراحل با گروه & \\
\hline$\cdot / r \Delta$ &.$/ 19$ & I/AF & $19 T / R \Delta$ & 1 & $19 \pi / \% \Delta$ & كرومها & \\
\hline 1 & $\cdot / \cdots 1$ & $F \mid / \wedge q$ & $19 \pi / \pi r$ & $1 / 11$ & $M N / 9 T$ & مراحل & روابط مثبت و نزديكك \\
\hline 1 &.$\cdots 1$ & $F G / D F$ & $|\Lambda| / F \Delta$ & $1 / 11$ & $r \cdot r / 9$. & تعامل مر احل با گرووه & \\
\hline$\cdot / v$ &.$/ \cdot 1$ & $9 / 91$ & INT/VD & 1 & INT/VD & كرومها & \\
\hline$\cdot / 9$ & $\%$ r r & $\mathrm{V} / \mathrm{r} \Lambda$ & IN/Ar & l/AF & TF/GT & مراحل & 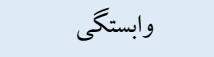 \\
\hline$\cdot / 99$ & $\cdot / \cdot \cdot 1$ & $9 / 99$ & $r \Delta / F \Delta$ & I/AF & $\notin q / 9$. & تعامل مراحل با گروه & \\
\hline . - (94 & 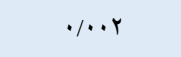 & $1 r / 4 q$ & $r A V \cdot / F I$ & 1 & $r \wedge V \cdot / F I$ & كرومها & \\
\hline 1 & $\cdot / \cdots 1$ & $q F I / F F$ & IGTVVV/TF & $1 / \cdot r$ & $199 \mathrm{r \Delta \Delta /Fr}$ & مراحل & كل \\
\hline .194 & $\cdot / \cdot r$ & $q / \mu F$ & $19 \mathrm{~V} / \mathrm{r}$. & $1 / \cdot r$ & IVY/YY & تعامل مر احل با گروه & \\
\hline
\end{tabular}

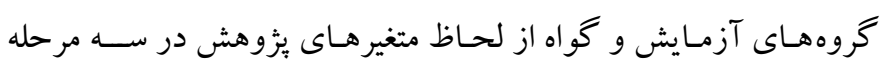

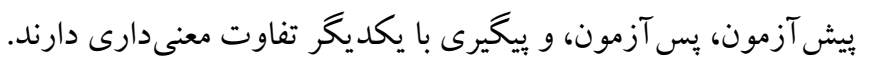

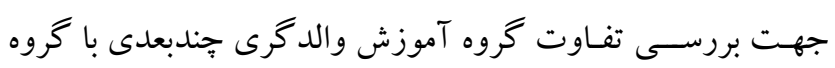

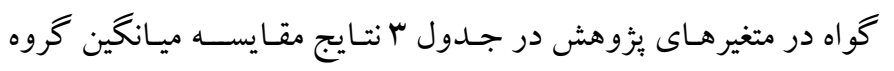

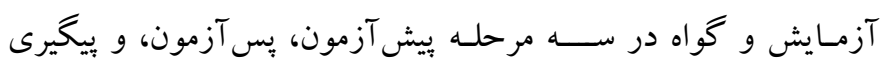

همان طور كه در جدول Y نشـان داده شـده است، ميزان F اثر تعامل

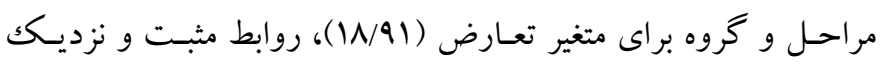

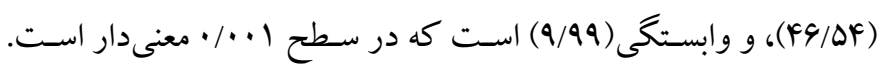

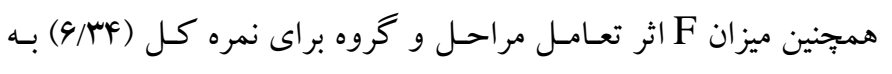

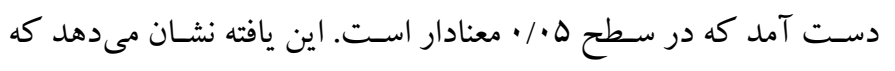

$$
\text { كزارش شده است. }
$$

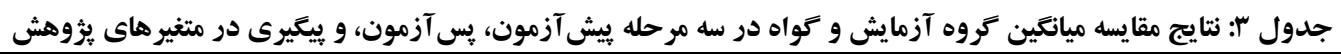

\begin{tabular}{|c|c|c|c|c|c|c|}
\hline سطح معنادارى & خطاى استاندارد بر آورد & تفاوت ميانكين & ميانكين كواه & ميانكين آزمايش & مرحله & متغير \\
\hline$\cdot / \mu_{1}$ & $r / 9 r$ & $r$ & $F F / v$ & $F V / V$ & يِيش آزمون & \\
\hline$\cdot / \cdots 1$ & $r / T$ & $-1 r / 94$ & Fr & $M_{1 / 4}$. & يس آزمون & ت تعارض \\
\hline$\% r$ & T/Y & $-11 / 4$ & $F F / Y \Delta$ & HY/AF & ييخيرى & \\
\hline$\% r$ & $r / \mu F$ & $\Lambda / \Delta$ & $r Y / q$. & $F \mid / F$. & ي ييش آزمون & \\
\hline$\cdot / \mathrm{VG}$ & l/Ar & $\cdot / \cdot \wedge$ & $f \cdot / F$. & $F I / r$ & 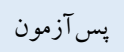 & روابط مثبت و نزديكك \\
\hline$\cdot / \cdots 1$ &.$/ 91$ & V/ar & $\mathrm{rV} / \cdot \wedge$ & $F F / V I$ & ييخيرى & \\
\hline . /AY & $1 / 4 \Delta$ & $-1 / 4$ & $1 \pi / \Lambda$ & $1 Y / 9$. & يِيش آزمون & \\
\hline.$/ 1$ &.$/ 99$ & $-Y / \Lambda \Delta$ & if & $1 \cdot / 4$. & يִ آزمون & وابستخى \\
\hline$\cdot / \cdots 1$ & $\cdot / v$ & $-F / 9 V$ & $14 / 9 \Lambda$ & $9 / \cdot 1$ & ييخيرى & \\
\hline$\cdot / \cdot r$ & $\Gamma / \Lambda$ & $-1 \cdot / \mu$ & $-\mid V / 1$ & $-Y V / F$. & يِيش آزمون & \\
\hline.$/ .14$ & $9 / \pi$. & $-19 / 91$ & $Q \Lambda / \Delta 9$ & $11 / 94$ & پِ آزمون & كل \\
\hline$\cdot / \cdot r$ & $F / Y F$ & $-19 / \mathrm{TV}$ & $9 \Lambda / 94$ & $\Lambda Y / 94$ & ييخيرى & \\
\hline
\end{tabular}




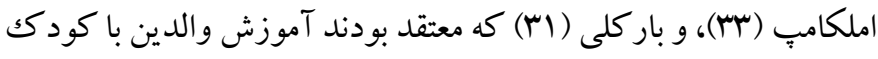

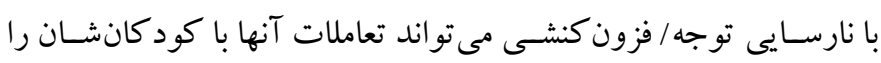

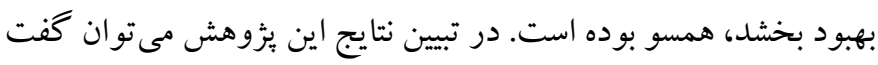

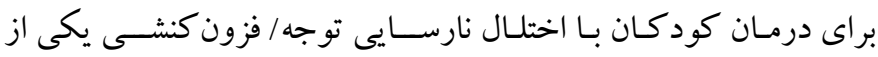

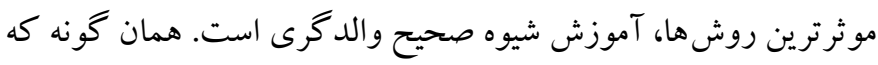

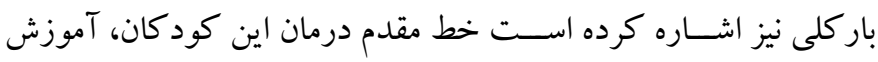

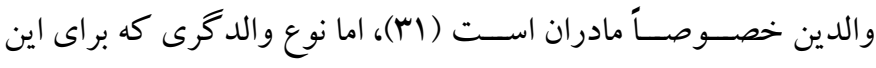

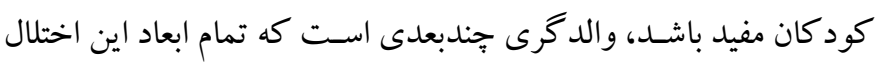

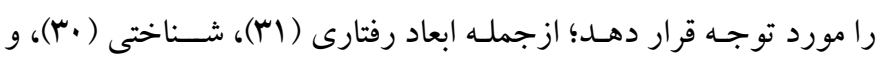

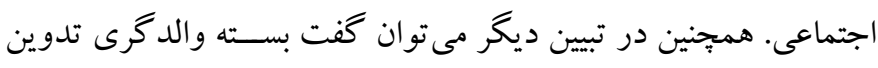

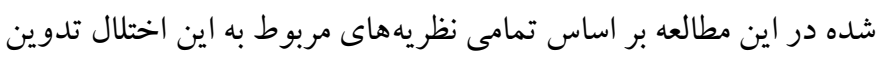

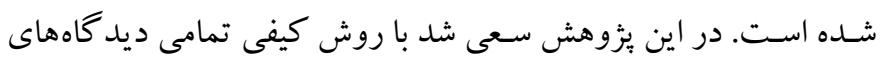

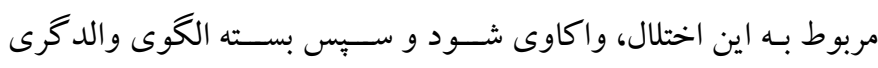
جندبعدى (بر اسـاس نظريات رفتارى، شــناختى، انسـان گركايانه، و غيره) تدوين شد؛ در نتيجه در آموزش ها به دليل اينكه حداكثر نيازهاى والدين

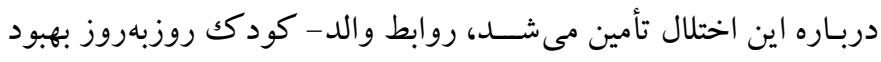

$$
\text { ييدا كرده است. }
$$

همجينين همان كونه كه بار كلى (اسM) نيز اشـاره كرده اسـت، مى توان

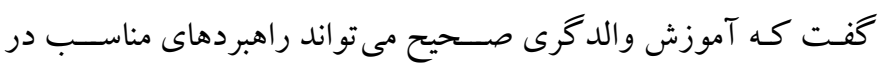

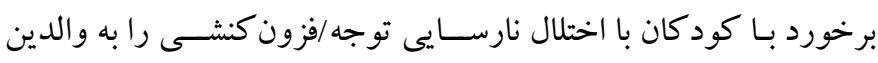
آموزش دهد و آنها را به روشهاى مناسـب جهت بازخورد دادن مناسب

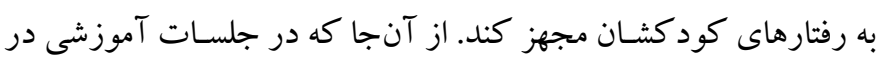

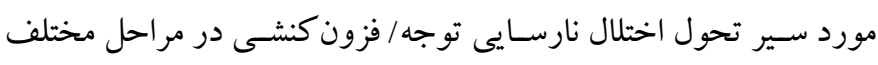

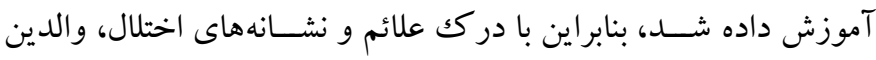

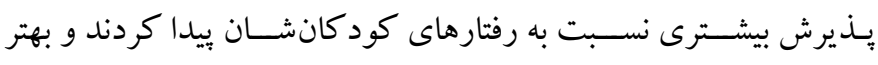

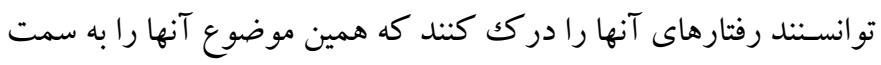

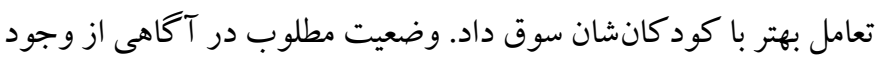

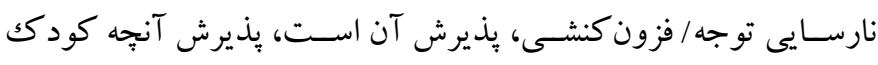

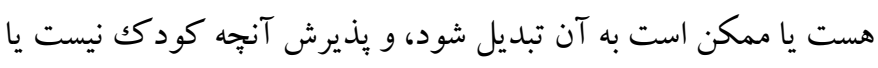

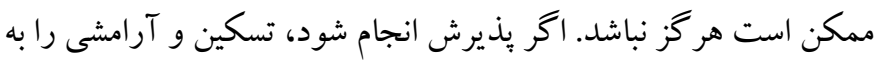

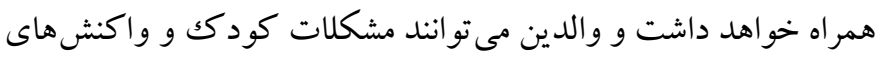

بـا توجـه بـه جـدول ب در متغير تعارض، تفاوت ميانگين گرروه

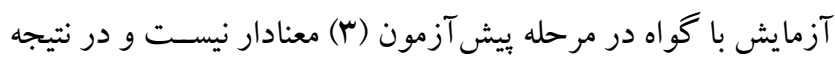

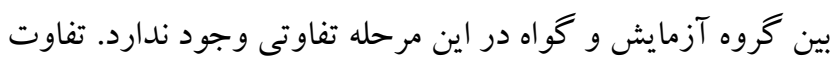

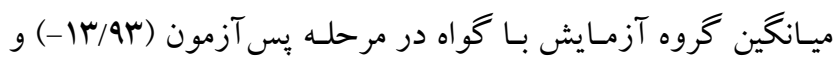

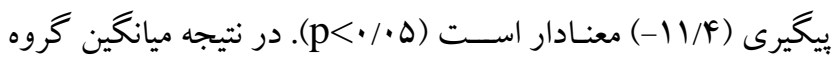
آزمايش در اين دو مرحله به صورت معنادارى كمتر از ميانگين گروه كواه اسـتـ. در متغير روابط مثبت و نزديكك تفاوت ميانكين گرووه

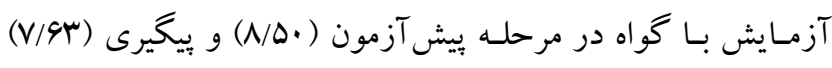

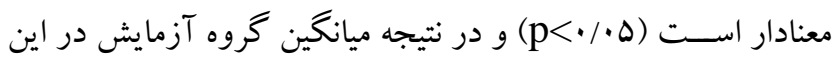

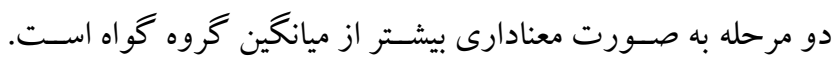

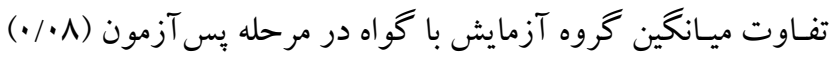

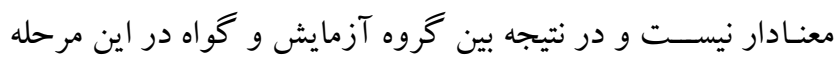

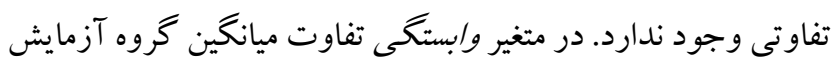

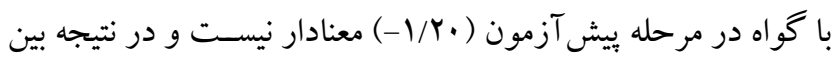

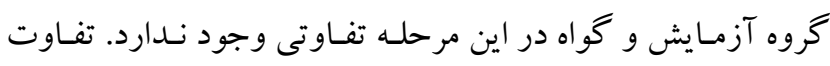

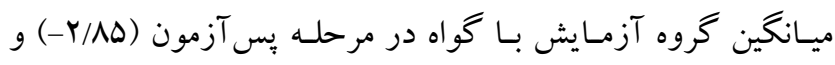
بيكيرى (F/ FV آزمايش در اين دو مرحله به صورت معنادارى كمتر از ميانخين گروه

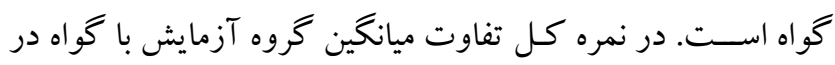

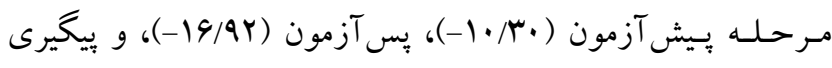

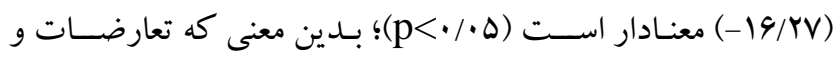

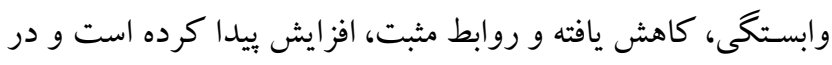
كل منجر به بهبود ارتباط والد- كودكك شده است.

\section{بحث و نتيجه كيرى}

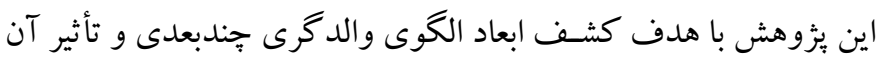

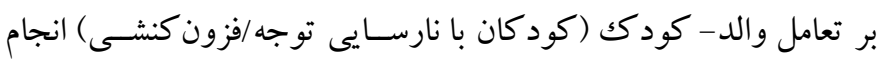

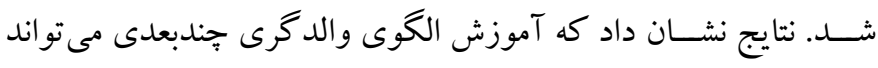

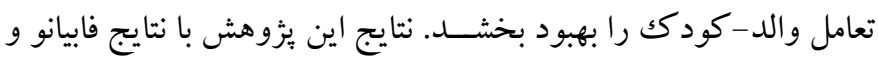

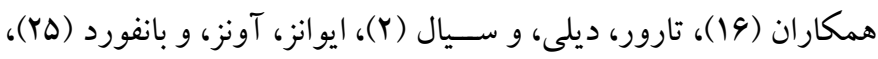

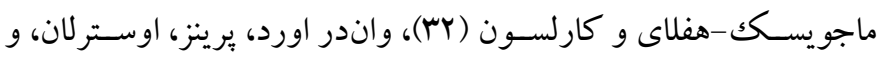


در متغير روابط مثبـت والـد - كودك نتـايج نشــان داد كـه آموزش والدكرى هندبعدى تو انسته اسـت روابط مثبت والد - كود كك را بهبود

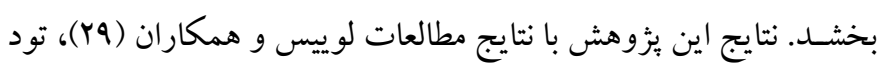

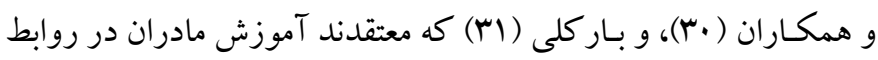

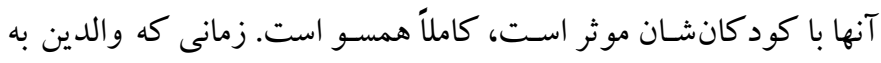

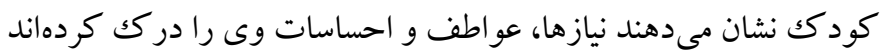

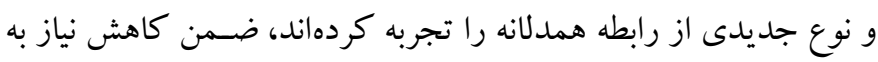

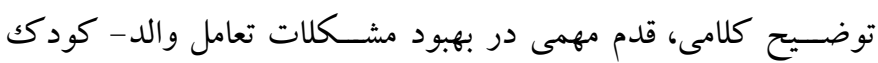

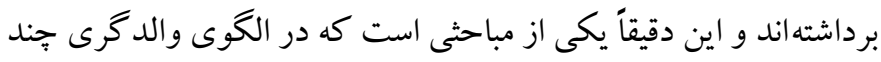

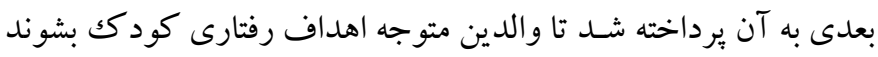

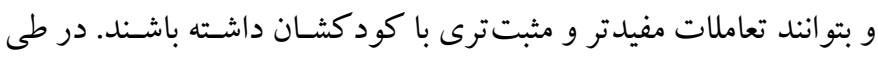

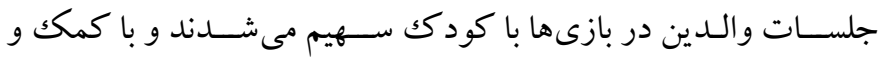

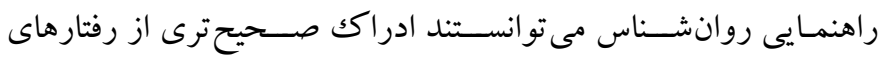
كود كك داشته باشند و ياسخ هاى مناسب ترى ارائه كنند.

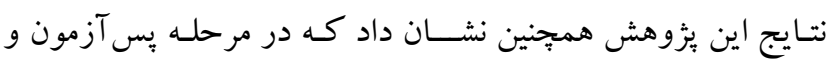

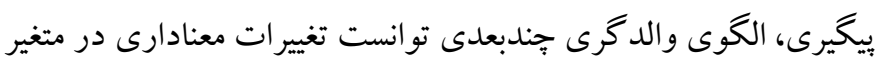

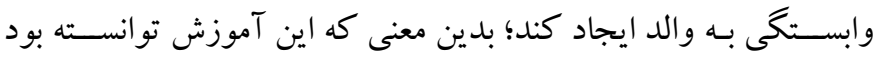

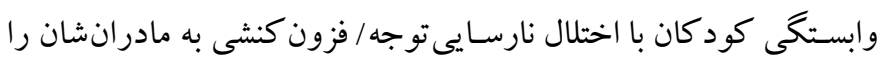

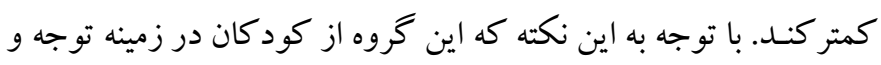

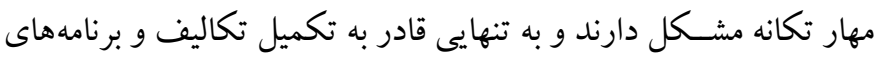

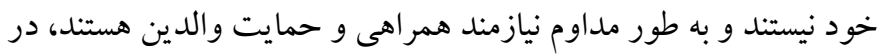

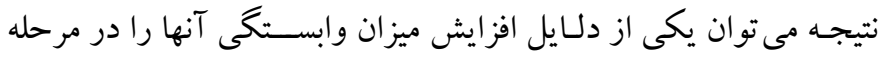

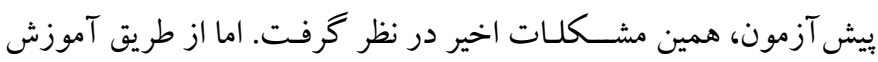

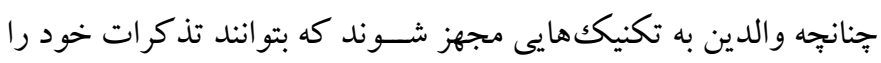

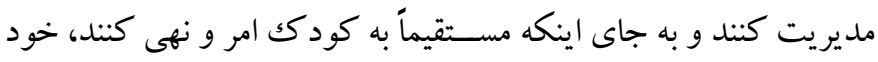

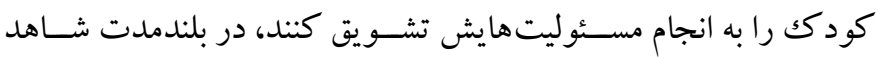

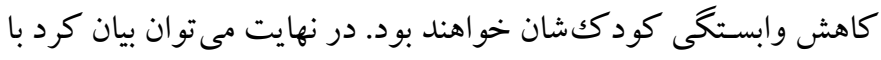

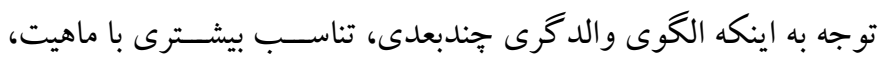

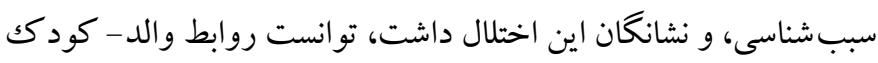

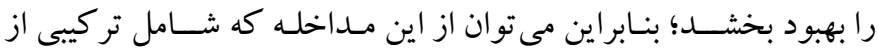

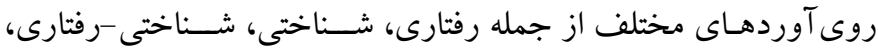

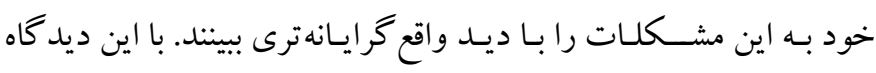

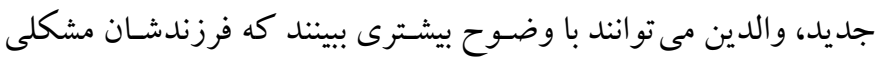

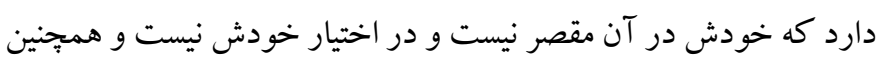
كود كك براى كنار آمدن با آن و محافظت در برابر كسانى كه اين مشكل

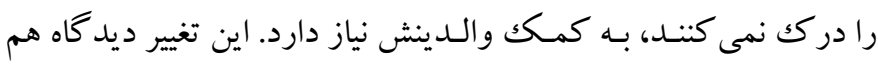

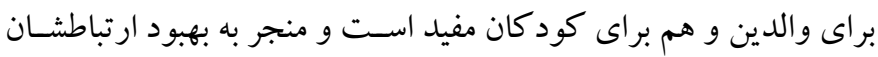
مىشود. همجِنين نتايج اين مطالعه نشـان داد كه در متغير تعارضات بين والد -

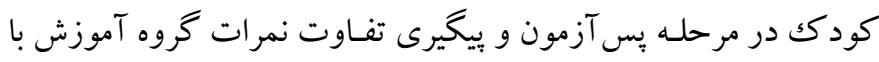

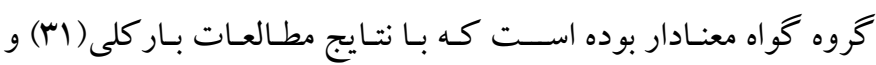
دانفورث (IV) همسو بود. يكى از عوامل و مفروضههاى به وجود آمدن

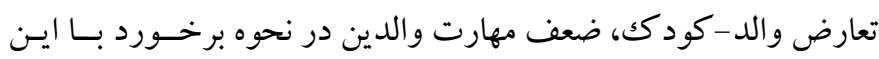

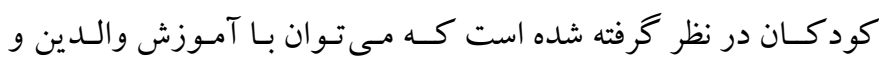

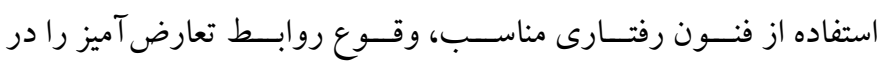

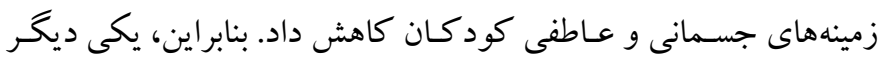

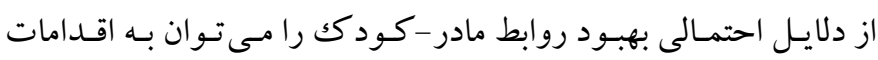
آموزشـى و تمرين هايى نسبت داد كه مادران در طول جلسات مداخلـه، خود را متعهد به انجام آنها مى دانستيند. به اين ترتيب، توجه مادئ مادران بيشتر

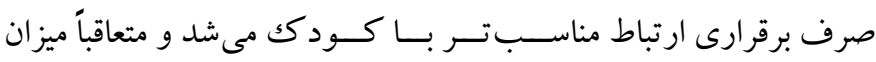
تنيدگى ناشسى از تحمـل رفتارهـاى كود كك كاهش مى يافت و تعاملات

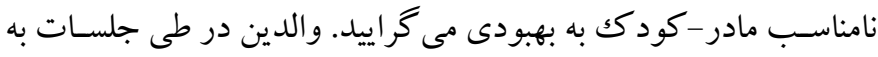

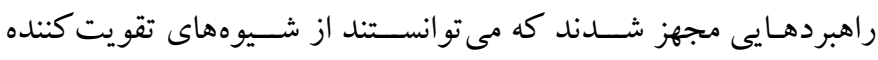

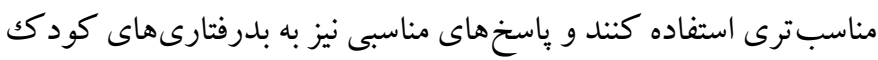

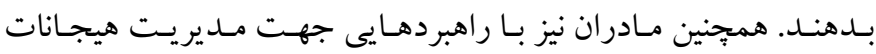
منفى شـان آشـنا شدند و بنابر اين از واكنش هاى فورى و نامناسب آنها در

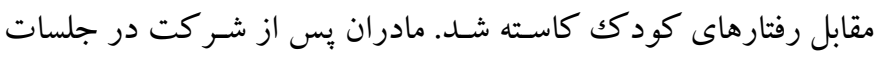

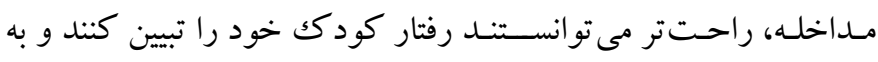

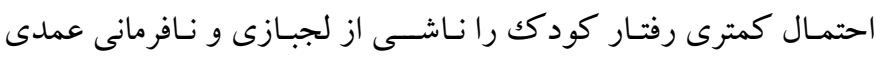

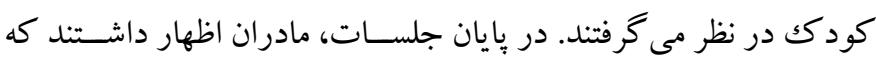
خيلى بهتر مى تو انـــد رفتـارهـاى كود كك خود را در كك كنتـد و كود كان حرفشنوى بيشترى داشتند. 
گَسترده در درمان مشكلات كود كان مبتلا به اين اختلال و خانواده آنها

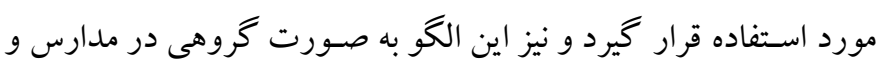

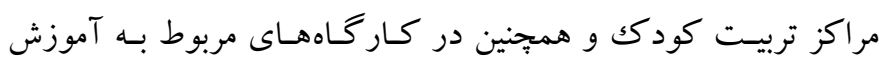

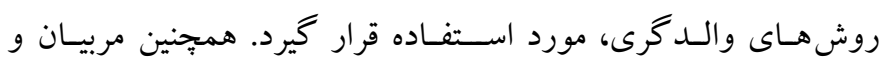

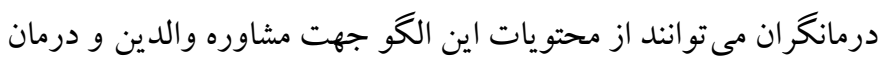
كود كان با اختلال نارسايى توجه/ فزون كنشى استفاده كنند.

تشكر و قدردانى: اين يزوهش بركرفته از رسـاله دكتراى خانم آرزو شاهميوه

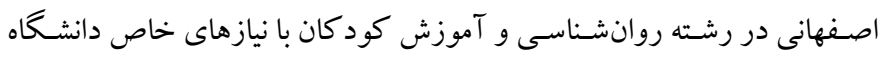

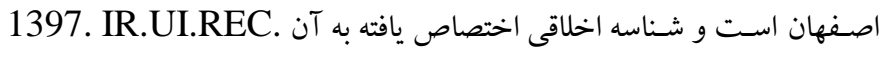

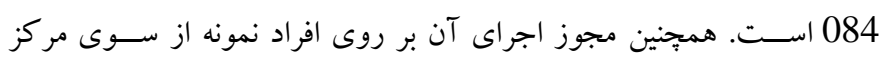

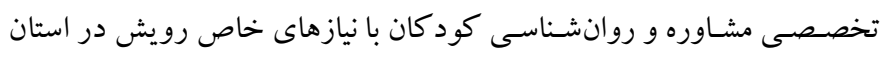

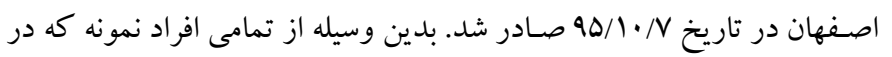

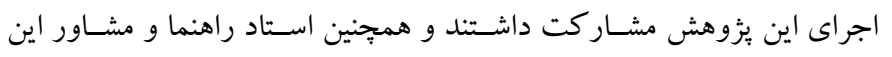
يُزوهش، تشكر و قدردانى مىشود. تضــاد منافع: نتايج اين يزوهش به صـورت شـفاف بيان شــدهاسـت و براى نويسند گان هيج گَونه تضاد منافعى به دنبال نداشته است.
انســان كرايانه، بازىدرمانى، و غيره بوده اســت براى بهبود تعامل والدـكود كك استفاده كرد.

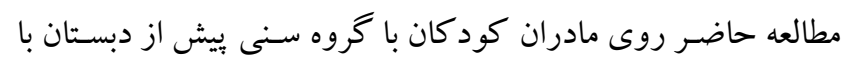

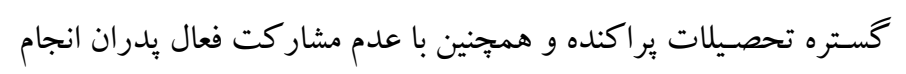
شده است كه در نتيجه تعميم نتايج بايد بر اساس همين موارد انجام شود.

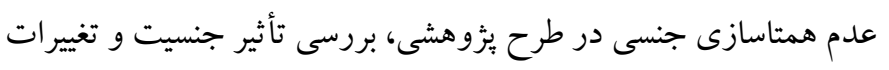

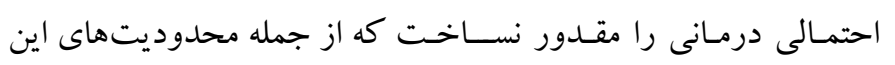

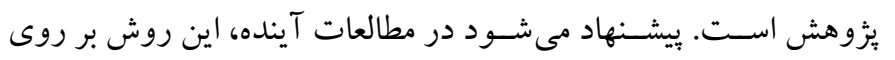

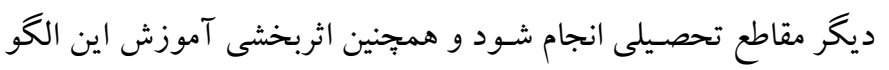

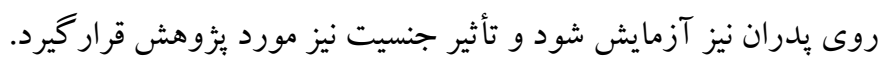

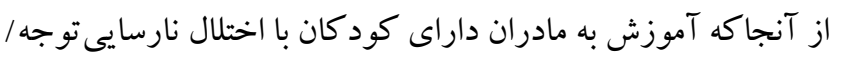

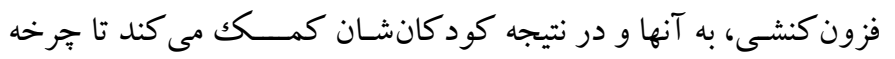

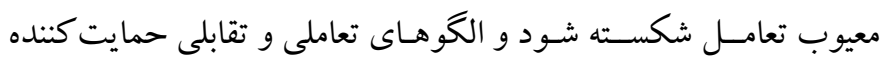

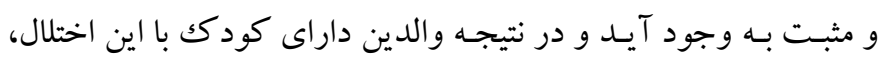
خو اهند توانسـت به صـورت سـازنده ترى با كودكى خود ارتباط برقرار

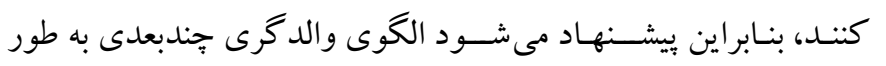




\section{References}

1. American Psychiatric Association. Diagnostic and statistical manual of mental disorders: DSM-5. 5th ed. Washington, DC: American Psychiatric Pub; 2013, pp: 102-104 [Link]

2. Tarver J, Daley D, Sayal K. Attention-deficit hyperactivity disorder (ADHD): An updated review of the essential facts. Child Care Health Dev. 2014; 40(6): 762-774. [Link]

3. Daley D, van der Oord S, Ferrin M, Danckaerts M, Doepfner M, Cortese S, et al. Behavioral interventions in attention-deficit/hyperactivity disorder: a metaanalysis of randomized controlled trials across multiple outcome domains. J Am Acad Child Adolesc Psychiatry. 2014; 53(8): 835-847. [Link]

4. Barkley RA. Attention-deficit hyperactivity disorder: a handbook for diagnosis and treatment. 3rd ed. Guilford Press; 2006, pp: 35-36. [Link]

5. DuPaul GJ, Langberg JM. Educational impairments in children with ADHD. In: Barkley RA, editor. Attention-deficit hyperactivity disorder: a handbook for diagnosis and treatment. 4th Ed. New York, NY, US: The Guilford Press; 2015, pp: 169-190. [Link]

6. Kuriyan AB, Pelham WE, Molina BSG, Waschbusch DA, Gnagy EM, Sibley MH, et al. Young adult educational and vocational outcomes of children diagnosed with ADHD. J Abnorm Child Psychol. 2013; 41(1): 27-41. [Link]

7. Johnston C, Jassy JS. Attention-deficit/hyperactivity disorder and oppositional/conduct problems: links to parent-child interactions. J Can Acad Child Adolesc Psychiatry. 2007; 16(2): 74-49. [Link]

8. Johnston C, Mash EJ. Families of children with attention deficit/hyperactivity disorder: review and recommendations for future research. Clin Child Fam Psychol Rev. 2001; 4(3): 183-207. [Link]

9. Sayal K, Washbrook E, Propper C. Childhood behavior problems and academic outcomes in adolescence: longitudinal population-based study. J Am Acad Child Adolesc Psychiatry. 2015; 54(5): 360-368. [Link]

10. Walerius DM, Reyes RA, Rosen PJ, Factor PI. Functional impairment variability in children with ADHD due to emotional impulsivity. J Atten Disord. 2018; 22(8): 724-737. [Link]

11. Factor PI, Reyes RA, Rosen PJ. Emotional impulsivity in children with ADHD associated with comorbid-not ADHD-symptomatology. J Psychopathol Behav Assess. 2014; 36(4), 530-541. [Link]
12. Rosen PJ, Factor PI. Emotional impulsivity and emotional and behavioral difficulties among children with ADHD: an ecological momentary assessment study. J Atten Disord. 2015; 19(9): 779-793. [Link]

13. Patterson GR, DeBaryshe BD, Ramsey E. A developmental perspective on antisocial behavior. Am Psychol. 1989; 44(2): 329-335. [Link]

14. Deault LC. A systematic review of parenting in relation to the development of comorbidities and functional impairments in children with attentiondeficit/hyperactivity disorder (ADHD). Child Psychiatry Hum Dev. 2010; 41(2): 168-192. [Link]

15. Smith MD, Barrett MS. The effect of parent training on hyperactivity and inattention in three school-aged girls with attention deficit hyperactivity disorder. Child Fam Behav Ther. 2002; 24(3): 21-35. [Link]

16. Fabiano GA, Schatz NK, Aloe AM, Chacko A, Chronis-Tuscano A. A systematic review of metaanalyses of psychosocial treatment for attentiondeficit/hyperactivity disorder. Clin Child Fam Psychol Rev. 2015; 18(1): 77-97. [Link]

17. Danforth JS. Training parents of children with comorbid attention-deficit /hyperactivity disorder and oppositional defiant disorder. In Briesmeister JM, Schaefer CE, editor. Handbook of parent training: helping parents prevent and solve problem behaviors. Hoboken, NJ, US: John Wiley \& Sons Inc. 2007; pp: 345-378. [Link]

18. Alizadeh H, Applequist KF, Coolidge FL. Parental self-confidence, parenting styles, and corporal punishment in families of ADHD children in Iran. Child Abuse Negl. 2007; 31(5): 567-572. [Link]

19. Gerdes AC, Hoza B, Pelham WE. Attentiondeficit/hyperactivity disordered boys' relationships with their mothers and fathers: child, mother, and father perceptions. Dev Psychopathol. 2003; 15(2): 363-382. [Link]

20. Keown LJ. Predictors of boys' ADHD symptoms from early to middle childhood: the role of fatherchild and mother-child interactions. J Abnorm Child Psychol. 2012; 40(4): 569-581. [Link]

21. Ellis B, Nigg J. Parenting practices and attentiondeficit/ hyperactivity disorder: partial specificity of effects. J Am Acad Child Adolesc Psychiatry. 2009; 48(2): 146-154. [Link]

22. Casas AM, Sevilla DG, Miranda BR, Taberner RM. Estilos de disciplina en familias con hijos con trastorno por déficit de atención/hiperactividad: influencia en la evolución del trastorno. Revista de neurología. 2007; 44(2): 23-25. [Link] 
23. Trenas AFR, Cabrera JH, Osuna MJP. El estilo de crianza parental y su relación con la hiperactividad. [Parenting styles and their relationship with hyperactivity.]. Psicothema. 2008; 20(4): 691-696. [Link]

24. Antshel KM, Barkley R. Psychosocial interventions in attention deficit hyperactivity disorder. Child Adolesc Psychiatr Clin N Am. 2008; 17(2): 421-437. [Link]

25. Evans SW, Owens JS, Bunford N. Evidence-based psychosocial treatments for children and adolescents with attention-deficit/hyperactivity disorder. J Clin Child Adolesc Psychol. 2014; 43(4), 527-551. [Link]

26. Pelham WE, Fabiano GA. Evidence-based psychosocial treatments for attentiondeficit/hyperactivity disorder. J Clin Child Adolesc Psychol. 2008; 37(1): 184-214. [Link]

27. Sanders MR, Turner KMT, Markie-Dadds C. The development and dissemination of the triple $\mathrm{P}$ positive parenting program: a multilevel, evidencebased system of parenting and family support. Prev Sci. 2002; 3(3): 173-189. [Link]

28. Webster-Stratton C, Reid MJ, Hammond $\mathrm{M}$. Preventing conduct problems, promoting social competence: a parent and teacher training partnership in head start. J Clin Child Adolesc Psychol. 2001; 30(3): 283-302. [Link]

29. Lewis TJ, Powers LJ, Kely MJ, Newcomer LL. Reducing problem behaviors on the playground: an investigation of the application of school wide positive behavior supports. Psychol Sch. 2002; 39(2): 181190. [Link]

30. Todd AW, Horner RH, Sugai G, Sprague J R. Effective behavior support: Strengthening schoolwide systems through a team-based approach. Effective School Practices. 1999; 17(4): 23-37. [Link]

31. Barkley RA. Taking charge of ADHD: the complete, authoritative guide for parents. Fourth edition. The Guilford Press; 2020, pp: 250-253. [Link]
32. Majewicz-Hefley A, Carlson JS. A meta-analysis of combined treatments for children diagnosed with ADHD. J Atten Disord. 2007; 10(3): 239-250. [Link]

33. Van der Oord S, Prins PJM, Oosterlaan J, Emmelkamp PMG. Efficacy of methylphenidate, psychosocial treatments and their combination in school-aged children with ADHD: a meta-analysis. Clin Psychol Rev. 2008; 28(5): 783-800. [Link]

34. Creswell JW, Clark VP, Garrett AL. Advanced mixed methods research. Handbook of mixed methods in social and behavioural research. Thousand Oaks, CA: Sage; 2003, 209-240. [Link]

35. Creswell JW, Plano Clark VL. Designing and conducting mixed methods research. Los Angeles: SAGE Publications; 2011, pp: 101-105. [Link]

36. Howitt D, Cramer D. Introduction to research methods in psychology. Pearson/Prentice Hall; 2005, p: 114. [Link]

37. Molavi H. Practical guide to SPSS 10-13-14 in behavioral science. Isfahan: Pouyesh Andisheh; 2008, p: 27. [Persian].

38. Pianta RC. Child-parent relationship scale (CPRS). University of Virginia; 1992. [Link]

39. Driscoll K, Pianta R. Mothers' and fathers' perceptions of conflict and closeness in parent-child relationships during early childhood. J Early Child Infant Psychol. 2011; 7: 1-24. [Link]

40. Khodapanahi MK, Ghanbari S, Nadali H, Seyed Mousavi P. Quality of mother-child relationships and anxiety syndrome in preschoolers. Journal of Developmental Psychology (Iranian Psychologists). 2012; 9(33): 5-13. [Persian]. [Link]

41. Pianta RC, Nimetz SL, Bennett E. Mother-child relationships, teacher-child relationships, and school outcomes in preschool and kindergarten. Early Child Res Q. 1997; 12(3): 263-280. [Link]

42. Sroufe LA, Fox NE, Pancake VR. Attachment and dependency in developmental perspective. Child Development. 1983; 54(6): 1615-1627. [Link] 